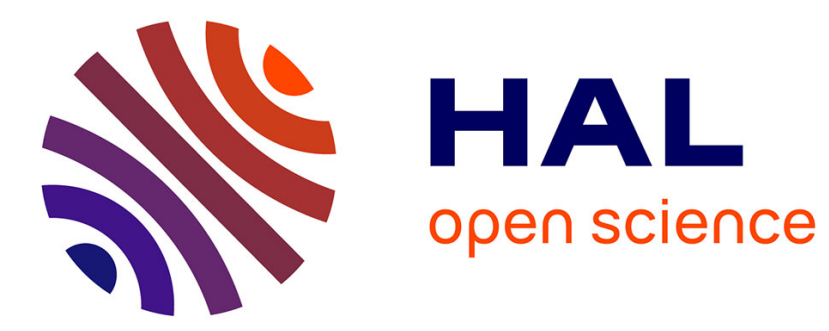

\title{
Urban agriculture in the developing world: a review
}

Francesco Orsini, Remi Kahane, Remi Nono-Womdim, Giorgio Gianquinto

\section{To cite this version:}

Francesco Orsini, Remi Kahane, Remi Nono-Womdim, Giorgio Gianquinto. Urban agriculture in the developing world: a review. Agronomy for Sustainable Development, 2013, 33 (4), pp.695-720. 10.1007/s13593-013-0143-z . hal-01201393

\section{HAL Id: hal-01201393 \\ https://hal.science/hal-01201393}

Submitted on 17 Sep 2015

HAL is a multi-disciplinary open access archive for the deposit and dissemination of scientific research documents, whether they are published or not. The documents may come from teaching and research institutions in France or abroad, or from public or private research centers.
L'archive ouverte pluridisciplinaire HAL, est destinée au dépôt et à la diffusion de documents scientifiques de niveau recherche, publiés ou non, émanant des établissements d'enseignement et de recherche français ou étrangers, des laboratoires publics ou privés. 


\title{
Urban agriculture in the developing world: a review
}

\author{
Francesco Orsini • Remi Kahane • \\ Remi Nono-Womdim • Giorgio Gianquinto
}

Accepted: 4 March 2013 /Published online: 9 May 2013

(C) INRA and Springer-Verlag France 2013

\begin{abstract}
The year 2007 marked a critical event in the world history. For the first time, more than half of the world population now lives in cities. In many developing countries, the urbanization process goes along with increasing urban poverty and polluted environment, growing food insecurity and malnutrition, especially for children, pregnant and lactating women; and increasing unemployment. Urban agriculture represents an opportunity for improving food supply, health conditions, local economy, social integration, and environmental sustainability altogether. Urban agriculture is present throughout the world in a diversity of farming systems. Urban dwellers ranging 25-30\% are involved worldwide in the agro-food sector. Urban agriculture will gain in recognition for its benefits and services because urban population and rural-urban migration are increasing. The actual scarcity of knowledge on urban agriculture has somehow hindered the relevance of this activity. Here, we review the social, cultural, technical, economic, environmental, and political factors affecting urban agriculture with examples taken in East Asia, South America, or East Africa. We discuss the definition, benefits, and limitations of urban agriculture. Food security benefit of urban agriculture is evidenced by $100-200$ million urban farmers worldwide providing the city markets with fresh horticultural goods.
\end{abstract}

F. Orsini $(\bowtie) \cdot$ G. Gianquinto

Department of Agricultural Sciences,

DIPSA, University of Bologna,

Viale Fanin, 44, 40127 Bologna, Italy

e-mail: f.orsini@uibo.it

R. Kahane

GlobalHort, c/o FAO-AGPM, Roma, Italy

R. Kahane

CIRAD, UR Hortsys, Montpellier, France

R. Nono-Womdim

Plant Production and Protection Division, FAO-UN,

Rome, Italy
Urban agriculture favors social improvement since the poors spend up to $85 \%$ of their income in food purchase and most urban farmers belong to poorest populations. Sociologically urban farming favors both social inclusion and reduction of gender inequalities, as $65 \%$ of urban farmers are women. Urban agriculture has ecological benefits by reducing the city waste, improving urban biodiversity and air quality, and overall reducing the environmental impact related to both food transport and storage. The production of horticultural goods shows the main benefits of urban agriculture. Fruit and vegetable crops give high yields, up to $50 \mathrm{~kg} \mathrm{~m}^{-2}$ year ${ }^{-1}$, a more efficient use of agricultural inputs, high added value, and rapidly perishable products that can easily substitute the rural production in the local market. Urban horticulture is the most competitive branch of urban farming due to the high cost of urban land and with the need of high water- and fertilizer-use efficiency. Traditional urban horticulture systems are classified in four types: allotment and family gardens, simplified extensive systems, shifting cultivation, and intensive systems. We describe also innovative systems including organoponics and simplified soilless cultures.

Keywords Biodiversity · Food and nutrition security . Food city supply $\cdot$ Agriculture and food systems . Simplified hydroponics $\cdot$ Urban agriculture . Water and waste management

\section{Contents}

1 Introduction. . . . . . . . . . . . . . . 2 2

2 Recognition of urban agriculture . . . . . . . . 4

3 Pros and cons of urban agriculture. ...........6

3.1 Food and nutrition security . . . . . . . . . . .7

3.2 Health . . . . . . . . . . . . . . . . . . . 7

3.3 Development of the local economies. . . . . . . . .7

3.4 Social inclusion and gender relations. . . . . . . . . .7

3.5 Ecological aspects and environmental impact. . . 8 
4 Urban horticulture ..................... . . 9

5 Factors that affect development and diffusion of urban horticulture .......................... 13

5.1 Apparent consumption ................. 13

5.2 Access to natural resources and labor . . . . . . . 13

5.3 Environmental pollution. . . . . . . . . . . . . . 15

5.4 Climatic conditions. . . . . . . . . . . . . . . . . 16

6 Traditional cultivation systems. . . . . . . . . . . . 17

6.1 Mixed farming systems on a limited acreage first target household consumption and small scale marketing. . . . . . . . . . . . . . . . . .17

6.2 Extensive mono-cropping systems for both home consumption and market. .............. 18

6.3 Shifting cultivation systems. . . . . . . . . . 18

6.4 Intensive horticultural cropping system on medium- or large-scale farms. . . . . . . . . . . . 18

7 Innovative cropping systems. . . . . . . . . . . . . 19

7.1 Organoponics......................19

7.2 Simplified hydroponic systems...........20

8 Conclusions. . . . . . . . . . . . . . . . . . 21

9 Acknowledgements ....................22

10 References.........................22

11 Tables. . . . . . . . . . . . . . . . . .

12 Figure captions. . . . . . . . . . . . . . . 9

\section{Introduction}

On May 23, 2007, for the first time in human history, the rate of population inhabiting urban centers overtook the rural one: Both the North Carolina and Georgia Universities have estimated that in that day the urban population reached 3.303.992.253 people, whereas rural population amounted at 3.303.866.404 (ScienceDaily 2007). The urban population expansion is more pronounced in developing countries as the result of rural-to-urban migration and natural population growth (FAO 2007; City Farmer 2011; FAO-FCIT 2011). At global level, an estimated 2 and $14 \%$ of the world population lived in cities in 1800 and in 1900, respectively. Projections indicate that by $2020,55 \%$ of the world population will live in the urban centers, and this percentage will rise up to 60 and $70 \%$ in 2030 and 2050, respectively (Table 1). It is also estimated that across emerging economies and developing countries an exceptional growth of urban population will be observed (UNFPA 2007; CFSC 2011). If in Latin America, already about $80 \%$ of the population live in cities, in Africa and Asia, the actual rates will double from 2000 by 2030 . The growing urbanization can also be observed among the metropolis (cities with more than 1,000,000 inhabitants), which were only 83 in 1950, and more than 400, with 21 megalopolis (over 10,000,000 inhabitants) in 2006 (Table 2). In 2020, it is foreseen that there will be at least 27 megalopolis, out of which 13 in Asia, 6 in Latin America, 5 between Europe and North America, and 3 in Africa (Batty 2008). The trend of urbanization is reversing in industrialized countries; rather than escaping from the cities toward rural areas, urban dwellers are now moving to smaller centers with good connections to the city. Annual urban growth rates are the most striking figures to describe situations in developing countries (4.58 \% in sub-Saharan Africa, 3.82\% in Southern-Eastern Asia, and $3.39 \%$ in Eastern Asia) (UN-HABITAT 2008a). Such figures mean that not only mega-cities are growing but also small and medium cities. The fastest growing city in Africa between 1990 and 2006 was Nakuru in Kenya for instance $(13.3 \%$ average annual growth, UN-HABITAT $2008 \mathrm{~b}$ ). Indeed, more than $53 \%$ of the world's urban population live in cities of fewer than 500,000 inhabitants (UNHABITAT 2008a). That has tremendous consequences in urban planning, not (well) anticipated in small cities, and in the fresh food supply in particular.

The urbanization process brings indeed a wide range of unwanted consequences, which go from the reduction of fertile lands to deforestation, air and water pollution, reduced drainage of the rainfall, and the creation of periurban areas where socio-economic constraints are exalted and poverty is condensed (Baud 2000). Historically, cities have served as engines of social progress and national economic growth. Over the past 60 years, there is a strong association between economic growth and urbanization, and most of the world's poorest nations remain among the least urbanized nations (Satterthwaite et al. 2010). Poverty was mainly found in rural areas and cities were places not of misery and despair but of opportunity for employment and improving living conditions through the economies of scale. However, during the past two decades, urban poverty has been increasing especially in least developed countries. As reported by Piel (1997), the world's poor once huddled largely in rural areas. In the modern world, they have gravitated to cities.

According to the United Nations (UN-HABITAT 2010), about $12.6 \%$ of the global population $(32.7 \%$ of urban population) lives in areas classified as slums. Furthermore, more than half of the urban population lives below the poverty line in Angola, Armenia, Azerbaijan, Bolivia, Chad, Colombia, Georgia, Guatemala, Haiti, Madagascar, Malawi, Mozambique, Niger, Sierra Leone, and Zambia. In other nations, such as for instance Burundi, El Salvador, Gambia, Kenya, Kirghizstan, Moldavia, Peru, and Zimbabwe, the percentage range from 40 to $50 \%$ (UNFPA 2007). Across the world, the population living in the city "slums" (also called "bidonvilles" or "favelas") is equal to about 1 billion people, out of which 220 million are in Africa, 598 million in Asia, and 134 million in Latin America (UN-HABITAT 2008a). In 
Table 1 Total and urban population in the World: historical series and projection 2000-2050 (source: UN-DESA 2007)

\begin{tabular}{|c|c|c|c|c|c|c|c|}
\hline \multirow[t]{2}{*}{ Year } & \multicolumn{7}{|c|}{ Total population (million) } \\
\hline & World & Africa & Asia & Europe & Latin America and Caribbean & North America & Oceania \\
\hline 2000 & 6,124 & 821 & 3,705 & 729 & 523 & 316 & 31 \\
\hline 2010 & 6,907 & 1,032 & 4,166 & 730 & 594 & 349 & 35 \\
\hline 2020 & 7,667 & 1,271 & 4,596 & 722 & 660 & 379 & 39 \\
\hline 2030 & 8,318 & 1,518 & 4,931 & 707 & 713 & 405 & 43 \\
\hline 2040 & 8,824 & 1,765 & 5,148 & 687 & 750 & 427 & 46 \\
\hline 2050 & 9,191 & 1,998 & 5,266 & 664 & 769 & 445 & 49 \\
\hline \multirow[t]{2}{*}{ Year } & \multicolumn{7}{|c|}{ Urban population $(\%)$} \\
\hline & World & Africa & Asia & Europe & Latin America and Caribbean & North America & Oceania \\
\hline 2000 & 46.6 & 35.9 & 37.1 & 71.4 & 75.3 & 79.1 & 70.4 \\
\hline 2010 & 50.6 & 39.9 & 42.5 & 72.6 & 79.4 & 82.1 & 70.6 \\
\hline 2020 & 54.9 & 44.6 & 48.1 & 74.8 & 82.3 & 84.6 & 71.4 \\
\hline 2030 & 59.7 & 50.0 & 54.1 & 77.8 & 84.6 & 86.7 & 72.6 \\
\hline 2040 & 64.7 & 55.9 & 60.3 & 81.0 & 86.8 & 88.5 & 74.3 \\
\hline 2050 & 69.6 & 61.8 & 66.2 & 83.8 & 88.7 & 90.2 & 76.4 \\
\hline
\end{tabular}

these agglomerates, the poor are more exposed to both work and food insecurity, and more subjected to violence and criminality. The lack of economical resources, and therein of political power, is the major cause of this vulnerability. Although food is easily found in local markets, most slum dwellers cannot afford its cost, especially for fruit and vegetables. The majority of the urban poor of Accra in Ghana and Kampala in Uganda spend most of their income to feed themselves; however, their food consumption remains insufficient in quality and quantity (Drescher 2004). Moreover, these people are more vulnerable to the macroeconomic fluctuations such as inflation and price rises (Garrett and Ruel 2000).

The poor management of resources in urban areas leads to a depletion of the opportunities of living in cities. Instruments and tools that could alleviate poverty are not available and may explain the dramatic increase in poverty in urban areas. The intervention of international development agencies in this field is relatively new (UNFPA 2007). The development of urban agriculture in general and urban horticulture in particular is one of the major strategies that is being spontaneously adopted in developing countries to address urban poverty and improve well being of city dwellers. Improving health conditions allows to develop a more sustainable and stable economic growth at both family and community levels. In peri-urban and rural areas of the tropics, human health issues are frequently related to malnourishment of the population affecting more than 2 billion people in 2000 according to FAO-WHO (WHO 2003). Fruits and vegetables are an important part of balanced diets and are widely recognized as a fundamental source of minerals, vitamins, and other antioxidant compounds in human nutrition. Nevertheless, in many regions of the developing world, the consumption of fruits and vegetables falls far short of the daily minimum intake of $400 \mathrm{~g}$ per person per day, or about $150 \mathrm{~kg}$ per person per year-recommended by the joint WHO-FAO Expert Consultation on Diet, Nutrition and Prevention of Chronic Diseases for the prevention of noncommunicable diseases and of micronutrient and vitamin deficiencies (WHO 2003) - both for a lack of tradition and culture in their cultivation and use, or simply because people do not have enough money to purchase them. In addition to their dietary benefits, fruits and vegetables are high value crops (Temu and Temu 2006) that can often provide excellent income generating opportunities for small-scale farmers, many of whom are women. Thus, improving health condition and reducing poverty may be pursued through the increase in fruit and vegetable cultivation and consumption. This is, however, going beyond simple technical innovation and organizational improvement: Giving to horticulture a role to play in food city supply is promoting diversification of crops and species, of farming and trading systems, and of consumption behaviors and habits. Such a diversification approach integrates linkages between rural and urban communities, combining sustainable production with responsible trade and consumption (FAO-FCIT 2011).

The present review aims to describe the state of the art of urban horticulture in developing countries, providing a critical overview of main available information on the subject. To date, the full recognition of the main features of urban horticulture has been hindered by a lack of good quality, reliable data. Although research has scarcely addressed this topic (Ruel et al. 1998, De Bon et al. 2010), a rather extensive literature may be found, ranging from technical documents, technical bulletins, and project reports. Therein, most of the hereby cited sources will not refer to academic studies, but often to nonscientific sources. 
Table 2 Population and average annual growth of Megacity (metropolitan area with a total population over 10 million people) in 2006 and 2020: a comparison with the largest Italian cities (source: Citymayors 2009a, b)

\begin{tabular}{|c|c|c|c|c|c|c|}
\hline Rank & Cities/urban areas & Country & $\begin{array}{l}\text { Population in } 2006 \\
\text { (million) }\end{array}$ & $\begin{array}{l}\text { Yearly growth rate } \\
(2006-2020, \text { in \%) }\end{array}$ & $\begin{array}{l}\text { Population in } 2020 \\
\text { (million) }\end{array}$ & Rank \\
\hline 1 & Tokyo & Japan & 35.53 & 0.34 & 37.28 & 1 \\
\hline 2 & Mexico City & Mexico & 19.24 & 0.90 & 21.81 & 5 \\
\hline 3 & Mumbai & India & 18.84 & 2.32 & 25.97 & 2 \\
\hline 4 & New York & USA & 18.65 & 0.66 & 20.43 & 9 \\
\hline 5 & São Paulo & Brazil & 18.61 & 1.06 & 21.57 & 6 \\
\hline 6 & Delhi & India & 16.00 & 3.48 & 25.83 & 3 \\
\hline 7 & Calcutta & India & 14.57 & 1.74 & 18.54 & 11 \\
\hline 8 & Jakarta & Indonesia & 13.67 & 3.03 & 20.77 & 8 \\
\hline 9 & Buenos Aires & Argentina & 13.52 & 0.97 & 15.48 & 12 \\
\hline 10 & Dhaka & Bangladesh & 13.09 & 3.79 & 22.04 & 4 \\
\hline 11 & Shanghai & China & 12.63 & 0.00 & 12.63 & 18 \\
\hline 12 & Los Angeles & USA & 12.22 & 0.58 & 13.25 & 15 \\
\hline 13 & Karachi & Pakistan & 12.20 & 3.19 & 18.94 & 10 \\
\hline 14 & Lagos & Nigeria & 11.70 & 4.44 & 21.51 & 7 \\
\hline 15 & Rio de Janeiro & Brazil & 11.62 & 0.93 & 13.23 & 16 \\
\hline 16 & Osaka-Kobe & Japan & 11.32 & 0.13 & 11.53 & 20 \\
\hline 17 & Cairo & Egypt & 11.29 & 1.56 & 14.02 & 13 \\
\hline 18 & Beijing & China & 10.85 & 0.19 & 11.15 & 21 \\
\hline 19 & Moskow & Russia & 10.82 & 0.58 & 11.73 & 19 \\
\hline 20 & Metro Manila & Philippines & 10.80 & 1.55 & 13.40 & 14 \\
\hline 21 & Istanbul & Turkey & 10.00 & 1.75 & 12.76 & 17 \\
\hline 22 & Paris & France & 9.89 & 0.21 & 10.18 & 23 \\
\hline 24 & Tianjin (Tientsin) & China & 9.39 & 0.55 & 10.14 & 24 \\
\hline 26 & Lima & Peru & 8.35 & 1.53 & 10.32 & 22 \\
\hline 27 & Bogotá & Colombia & 7.80 & 1.84 & 10.08 & 26 \\
\hline 35 & Lahore & Pakistan & 6.57 & 3.12 & 10.10 & 25 \\
\hline 39 & Kinshasa & Congo & 5.89 & 3.89 & 10.04 & 27 \\
\hline 68 & Milan & Italy & 3.96 & -0.46 & 3.71 & 113 \\
\hline 113 & Naples & Italy & 2.88 & -0.33 & 2.75 & 161 \\
\hline 132 & Rome & Italy & 2.60 & -0.46 & 2.43 & 195 \\
\hline
\end{tabular}

\section{Recognition of urban agriculture}

Agriculture has always been associated with the imaginary of the rural environment, and as a matter of fact, its related activities were most of the time confined to such context. Based upon this, for long time, it has been considered that, in order to feed the urban population, it would be sufficient to rely on the rural crop production. For many cities of the world developing countries, however, this turned out to be rather wrong, mainly as a consequence of the scarce infrastructures (transports, roads, markets, etc...) and for the low purchasing power of the indigent population (Drescher 2004). With the time, indeed, the increase in poverty and the high unemployment rates, altogether with the opportunities that the city, on the other hand, can offer — such as the food demand and the vicinity to the markets - have stimulated the development of a variety of cropping and food systems in the cities and their surroundings, mainly specialized in the production of fresh vegetables, milk, eggs, and chickens (Table 3). The term urban agriculture was coined to describe both plant cultivation and animal rearing for home consumption and income generation in cities. Moreover, urban agriculture includes other interrelated activities, such as the production and selling of agricultural inputs, and postharvest handling and marketing of agricultural produce (Table 4). The main features of this type of activities are as follows:

- Urban agriculture is defined as production in the home or plots in urban or peri-urban areas. As such, it is in most of the cases an informal activity quite difficult to 
Table 3 Origin of different food items sold/consumed in Kumasi, Ghana (Moustier and Danso 2006)

\begin{tabular}{llll}
\hline Food item & $\begin{array}{l}\text { Urban } \\
\text { area (\%) }\end{array}$ & $\begin{array}{l}\text { Peri-urban } \\
\text { area (\%) }\end{array}$ & $\begin{array}{l}\text { Other sources } \\
\text { (rural areas or import) (\%) }\end{array}$ \\
\hline Cassava & 10 & 40 & 50 \\
Mais & $<5$ & 5 & 90 \\
Platan & $<5$ & $<10$ & 85 \\
Yam & 0 & 0 & 100 \\
Cocoyam & $<2$ & $<10$ & 90 \\
Rice & 0 & $<5$ & 95 \\
Lettuce & 90 & 10 & 0 \\
Tomato & 0 & 60 & 40 \\
Eggplant & 0 & 60 & 40 \\
Onion & 0 & 0 & 100 \\
Leak & 90 & $<10$ & 0 \\
Chicken/eggs & 15 & 80 & $<5$ \\
Meat & 5 & 10 & 85 \\
Fresh milk & $>95$ & $<5$ & 0 \\
\hline
\end{tabular}

characterize with accurate data and trends (Ruel et al. 1998; FAO 2003).

- Urban agriculture includes vegetable and fruit tree cultivation, as well as other specialized crops (e.g., medicinal and ornamentals), wood production, small-scale animal rearing (ranging from common, such as bovines and poultry, to local species, such as Guinea pigs), bee keeping, and also aquaculture (combined fish and plant culture) (Drescher and Iaquinta 1999; Mougeot 1994; FAO 2001; Ghosh 2004).

- It is generally conducted near markets;
- Owing to the high competition for land, it occurs in limited spaces.

- Urban agriculture uses city water and recycles organic discards. It has, therefore, a beneficial role in managing natural resources for a sustainable environment (FAO 2010);

- Its produce is freshly marketed, without further processing;

- Most farmers involved in the urban agricultural activities are characterized by a low level of organization.

At present urban agriculture is complementary to the rural production (mainly by providing perishable products such as vegetables, milk, and eggs, Table 3), and it is now well established that it improves food systems for city supply (van Veenhuizen 2006). Evidences of the increasing role of urban agriculture are available for several cities: Urban agriculture occupies more than 21,000 ha in Cagayan de Oro City (Philippines) (Potutan et al. 2000); in Havana-Cuba, about $12 \%$ of urban land is dedicated to agriculture (Cruz and Medina 2003); and more than 11,000 ha are used for agricultural production in Jakarta (Indonesia) (Purnomohadi 2000). The production appears to be extremely diversified, and it includes among other things corn, vegetables, flowers, and livestock production within the city of Harare (Zimbabwe) (Ghosh 2004). About 100,000 tons of fresh foods are produced in Dar es Salaam (Tanzania) yearly (Ratta and Nasr 1996); $100 \%$ of milk and $90 \%$ of eggs consumed in Shanghai (China) are produced within the city boundaries (Yi-Zhang and Zhangen 2000).

However, according to Mougeot (2000), the most important feature of urban agriculture is not merely represented by its localization within the city boundaries but by its increasing relevance in the urban texture both at a socio-economical and

Table 4 Main typology of socio-economic profiles of urban farmers (adapted from Moustier and Danso 2006)

\begin{tabular}{|c|c|c|c|c|}
\hline & Small-scale agriculture & $\begin{array}{l}\text { Small-scale commercial } \\
\text { agriculture }\end{array}$ & Farming enterprises & Nonspecialized farming \\
\hline $\begin{array}{l}\text { Main location where } \\
\text { it is found }\end{array}$ & Urban (peri-urban) & Urban and peri-urban & Peri-urban (urban) & Peri-urban \\
\hline Product destination & Household & Urban markets & Urban market + export & $\begin{array}{l}\text { Household + urban } \\
\text { markets }\end{array}$ \\
\hline Main aim & Self-consumption & Small income generation & $\begin{array}{l}\text { Main or part-time activity } \\
\text { for income generation }\end{array}$ & $\begin{array}{l}\text { Self consumption }+ \text { small } \\
\text { income generation }\end{array}$ \\
\hline Size & $<100 \mathrm{~m}^{2}$ & $<1,000 \mathrm{~m}^{2}$ & $>2,000 \mathrm{~m}^{2}$ & $>5,000 \mathrm{~m}^{2}$ \\
\hline Products & $\begin{array}{l}\text { Leafy veggie, cassava, } \\
\text { plantain, corn, fruits, } \\
\text { chickens, sheep }\end{array}$ & $\begin{array}{l}\text { Leafy veggie, other vegetables, } \\
\text { chickens, sheep, milk }\end{array}$ & $\begin{array}{l}\text { Leafy veggie, other vegetables, } \\
\text { chickens, animal rearing, } \\
\text { aquaculture }\end{array}$ & $\begin{array}{l}\text { Cereals, legumes, roots } \\
\text { and tubers, traditional } \\
\text { vegetables }\end{array}$ \\
\hline Technological level $^{\mathrm{a}}$ & Low & Low to medium & Medium to high & Very low \\
\hline Main gender & Women & Both & Men & Both \\
\hline Limiting factors & Land size & $\begin{array}{l}\text { Land size, access to land } \\
\text { and to agricultural input, } \\
\text { market fluctuations }\end{array}$ & $\begin{array}{l}\text { Technical knowledge, } \\
\text { market fluctuations }\end{array}$ & $\begin{array}{l}\text { Access to agricultural } \\
\text { inputs, soil fertility }\end{array}$ \\
\hline
\end{tabular}

${ }^{a}$ Related to the agricultural input used 
ecological perspective. Therefore, urban agriculture affects and is also affected by the urban environment. Urban agriculture:

- Uses the city resources (land, labour, organic wastes, water)

- Feeds the city inhabitants

- Is strongly influenced by the contingent conditions (policies, land competition, market presence, price trends, and quality standards)

- Plays a crucial role on the socio-economical conditions (effects on food security, poverty, health, and environment) of urban dwellers.

While many of the other activities are most of the time transitional, urban agriculture is likely to become a permanent feature of most cities, both in developing and developed countries. The rate of urban population involved in agriculture is estimated at about $50 \%$ in Accra, Ghana (Obosu-Mensah 2002), while according to both van Veenhuizen (2006) and Shackleton et al. (2009), $80 \%$ in Brazzaville (Congo), $68 \%$ in the five biggest cities of Tanzania, $45 \%$ in Lusaka (Zambia), $37 \%$ in Maputo (Mozambique), $36 \%$ in Ouagadougou (Burkina Faso), and $35 \%$ in Yaoundé (Cameroon). In Kenyan cities, about $29 \%$ of the families are employed in urban farming (Ghosh 2004). From a study of Zezza and Tasciotti (2010) - using survey data from fifteen countries across the four principal development regions, i.e., Asia (Bangladesh, Indonesia, Nepal, Pakistan, and Vietnam), Africa (Ghana, Madagascar, Malawi, and Nigeria), Eastern Europe (Albania and Bulgaria), and Latin America (Ecuador, Guatemala, Nicaragua, and Panama) - the shares of urban households that earn income from agriculture vary from $11 \%$ in Indonesia to almost $70 \%$ in Vietnam and Nicaragua. In 11 of the 15 countries in dataset, the share of households participating is over $30 \%$.

These figures clearly indicate the important role of urban agriculture among the activities of the informal sector (Mbiba 1995; Obosu-Mensah 1999). During the past 25 years, the number of actions (at international, national, and local levels) addressing the promotion of urban agriculture has increased steadily, though there is still a certain institutional reluctance for the inclusion of urban agriculture in urban master plans (Drescher 2001; Cissé et al. 2005). For instance, in the peri-urban areas of Nairobi (Kenya) and many other African cities, agriculture was discouraged and for long time forbidden in order to prevent street criminals to hide (Foeken and Mwangi 1998; Ghosh 2004; Ayaga et al. 2005). On the opposite side, there are many countries where governments promote the development of urban agricultural production. In Latin America, Argentina, Brazil, and Cuba have developed national policies and programs that promote urban horticulture (van Veenhuizen 2006). In
Africa, the Democratic Republic of the Congo has created an effective institutional structure for national urban horticulture development. Municipal committees chaired by city mayors manage the process of regularizing titles to land for horticulture and integrating urban horticulture into urban planning, while the country's national urban horticulture support service provides technical advice to growers through a network of offices in 11 provincial capitals (FAO 2010). In Shanghai (China), a program that promotes the city selfsufficiency in cereals allows a yearly production of 2 million tons of wheat (Yi-Zhang and Zhangen 2000). In Cagayan de Oro City (Philippines), the local government in collaboration with Xavier University adopted measures that aimed at facilitating the cultivation of community gardens among the poorest households (Holmer et al. 2003; Holmer and Drescher 2005). In Accra (Ghana), the Ministry of Food and Agriculture pledged its support for urban agriculture in a Vision Statement (Obuobie et al. 2006) and started on different sites in the city to explore the ground for safer irrigation water. Following a directive from the central government, the municipality of Bamako (Mali) started to explore the possibilities of leasing to farmers up to 600 ha near Bamako's international airport (Velez-Guerra 2004). In Niamey (Niger), the overall urban development plan of the city considers the intensification of irrigated and rainfed agriculture, particularly along the Niger River (Cissé et al. 2005). Moreover, the United Nations have indicated that the promotion of urban agriculture is one of the key strategies to address the Millennium Development Goals (Mougeot 2005).

As a consequence of the increased awareness on the important role of urban agriculture, new research activities have taken place in this field since the early 1990s. For instance, the International Development Research Centre (IDRC Canada) led efforts to support the urban agriculture initiatives worldwide. In 2000, the Consultative Group on International Agricultural Research (CGIAR) included urban agriculture among the research priorities, through an innovative system wide program called "Urban Harvest." Since then, several National Research Centres in Argentina, Kenya, Senegal, and Niger, to name a few, have included urban agriculture in their research programmes (van Veenhuizen 2006). It seems that promoting urban agriculture was not fully politically correct since both programs of IDRC and CGIAR have ended at about the same time in 2010 and have not been taken over despite huge amount of experience and lessons learned (Prain et al. 2010).

\section{Pros and cons of urban agriculture}

As defined above, urban agriculture presents social, environmental, and economic impacts on the city (Fleury and Ba 2005). Urban agriculture positively contributes to many 
of the problems affecting the urban environment. At the same time, when using poor practices, it can have a negative impact on human health and the environment. Consequently, guidelines on appropriate urban and periurban agricultural practices are required, which can be properly understood and followed only with a higher awareness of the population (all consumers, actors of the food chain, and policy makers as well) and a better education. The main strengths and weaknesses of urban agriculture may be synthesized as follows (Drescher 2004; Ghosh 2004; van Veenhuizen 2006):

\subsection{Food and nutrition security}

The contribution of urban agriculture to food and nutrition security is probably its main strength, since agricultural production in cities provides the poorest with a greater access to food (Maxwell et al. 1998) filling an essential share of nutritional needs (Gockowski et al. 2003; Kahane et al. 2005; Smith and Eyzaguirre 2007). In a study where descriptive statistics and multivariate analysis were used to assess how participation in urban agriculture impacts dietary adequacy (Zezza and Tasciotti 2010), the results confirmed that engagement in farming by urban households can allow them consuming better, more nutritious diets.

Of the estimated 800 million people engaged worldwide in urban agriculture, 200 million produce for the market (ArmarKlemesu 2000). These data are likely overestimated, since they are mainly derive from estimates by the Urban Agriculture Network based on individual experiences and observations and extrapolation from data. As a matter of fact the amount of quantitative work on urban agriculture that has been published is limited (Zezza and Tasciotti 2010), and one substantial strand of the literature on urban agriculture is driven by an advocacy objective, more than by analytical rigor (Ellis and Sumberg, 1998). FAO evaluations (1996) are more conservative than those cited above, stating that 100 million people are estimated to earn some income directly from urban farming.

Table 5 lists various estimated contributions of urban agriculture to income generation in various African cities.

\subsection{Health}

An easier access to safe and nutritious food (mainly fresh products) helps improve health conditions of the urban poor. However, the agricultural production in polluted areas of the cities may pose a serious threat to public health. This aspect still remains essentially unexplored (Birley and Lock 2000; Danso et al. 2003; Aubry et al. 2012), but should not be overlooked, and therein, regulation and prevention measures should be reinforced. All risks that are usually encountered in traditional rural farming should be carefully considered. Following the assessment in wastewater quality made in
Nairobi, Kenya by Karanja et al. (2010), the major challenges to address include:

- Contamination by pathogens that results: (a) from irrigation with polluted water, (b) inappropriate use of organic fertilizer (e.g., fresh animal dejections or non composted urban wastes that are in direct contact with edible parts of the plants), and (c) poor hygienic practices during post harvest and handling activities (viz., transport, transformation and marketing)

- Contamination as a consequence of inappropriate use of pesticides

- Contamination of soil and products with heavy metals as a consequence of agricultural production along roads with high traffic or near industrial discharges

- Disease transmission to human from animal production (viz., bird flu)

- High occurrence of insects/disease vectors (e.g., mosquitoes) attracted by the agricultural production (Klinkenberg et al. 2008).

\subsection{Development of the local economies}

As previously indicated urban farming is a source of income for many urban poor, and it allows reducing the costs of food purchase, since it is estimated that those urban poor spend between 60 and $85 \%$ of their income just to feed themselves (Mougeot 2005; Redwood 2008). This makes them highly vulnerable to food price hikes (Zezza et al. 2008; Dessus et al. 2008). The slum dwellers who grow their own food can provide food for their families and thereby reduce the costs of food purchase (Moustier and Danso 2006; IDRC 2011). Urban farming creates job opportunities (Agbonlahor et al. 2007) and stimulates the growth of enterprises in the related activities (e.g., farming inputs, food processing, packaging, marketing, etc.) (IIED 2011).

Although urban agriculture does not appear to be the major urban economic activity, in a number of countries, there is a significant share of the urban population that relies on the production of crop and livestock products for their livelihoods (Zezza and Tasciotti, 2010). Urban agriculture is eminently an activity practiced by the poor, and, with the rise of food demand in cities, small-scale farming gradually shift from subsistence farming to commercial farming (Cour 2001; Dossa et al. 2011). As a matter of fact, with few exceptions, a clear negative correlation between participation in agricultural activities and level of welfare has been noted (Zezza and Tasciotti 2010).

\subsection{Social inclusion and gender relations}

Urban farming is an important mean for the integration of disadvantaged people or social groups (e.g., immigrants, 
Table 5 Monthly net income from irrigated mixed vegetable farming and General Net Income (UN statistics) in West and East Africa (adapted from Drechsel et al. 2006)

${ }^{\mathrm{a}}$ The interval reflects seasonal fluctuations

\begin{tabular}{llll}
\hline Country & City & $\begin{array}{l}\text { Mean monthly net income } \\
\text { per farm (US\$/month) }\end{array}$ & $\begin{array}{l}\text { Per capita income at national } \\
\text { level (US\$ } / \text { month) }\end{array}$ \\
\hline Benin & Cotonou & $50-110$ & 36 \\
Burkina Faso & Ouagadougou & $15-90$ & 25 \\
Cameroon & Yaoundé & $34-67$ & 53 \\
Congo & Brazzaville & $80-270$ & 53 \\
Gambia & Banjul & 30 & 26 \\
Ghana & Accra & $40-57$ & 27 \\
Ghana & Kumasi & $35-160$ & 27 \\
Ghana & Takoradi & $10-30$ & 27 \\
Guinea-Bissau & Bissau & 24 & 12 \\
Kenya & Nairobi & $10-163$ & 33 \\
Liberia & Freetown & $10-50$ & 13 \\
Mali & Bamako & $10-300$ & 24 \\
Niger & Niamey & 40 & 17 \\
Nigeria & Lagos & $53-120$ & 27 \\
Central African Rep. & Bangui & 320 & 22 \\
Senegal & Dakar & $40-250$ & 46 \\
Tanzania & Dar Es Salaam & 60 & 24 \\
Togo & Lome & $30-300$ & 26 \\
\hline & & &
\end{tabular}

indigent or left women, unemployed, elders, disabled, etc.) since it promotes and ease their participation in the social texture and provides them with better living conditions (Novo and Murphy 2000). Many advantages, both on the individual wellness than on the sustainability of the activities, are found when the cultivation is operated at group or associations level, since the negative impact of the market fluctuations are less severe, both the entrepreneurial risk and the costs are reduced (e.g., for renting the lands, transports, technical assistance), and the contracting power is improved. Moreover, the group may access to easier relations with the institutional actors (e.g., for access to land, credit, and markets), and with national and international development agencies. Finally, within the groups, the interpersonal relations among producers are strengthened (Smit and Bailkey 2006; Orsini et al. 2009). Such association may play a crucial role in the training of farmers, in the development of infrastructure, in the processing, marketing, and quality control of produce (van Veenhuizen 2006). Urban farming also plays a crucial role in recreational and educational activities. This is particularly true for the youth. In the community gardens of North East of Brazil, it is common to find children playing in the gardens and helping their parents to grow plants (Fig. 1). This keeps them away from the street and at the same time provides them with knowledge on some agricultural practices that alternatively would be lost within few generations. Moreover, it allows creating or maintaining biodiversity, with a transfer of knowledge between grandparents and children on the traditional practices and species. At school, gardens play an important educational function allowing to better describe concepts of not only biology and agronomy but also mathematics, physics, and chemistry (FAO School Gardens 2005; Smit and Bailkey 2006; Mezzetti et al. 2010). Evidence from cities around the world underscores the positive impact of urban agriculture on women, youth, and children (e.g., Mawois et al. 2011). Worldwide, it is estimated that about $65 \%$ of urban farmers are women (van Veenhuizen 2006). These women often occupy managerial position (e.g., group coordinator, representative in the management group, associate in institutionally recognised bodies, etc.), and this allows for a better integration in the social texture of the community (Diaz-Albertini 1991; Oths 1998; Orsini et al. 2009; FAO Gender 2011).

\subsection{Ecological aspects and environmental impact}

Pollution in rapidly expanding cities poses a serious threat to public health. Of a paramount importance is waste management that represents a serious concern in most cities worldwide. Waste management to urban agriculture can help to keep the urban environment clean and boost production of fresh food (Smit et al. 1996) through the production of compost from organic wastes and the recycling of inorganic wastes (such as, for instance, the use of plastic bottles, tanks, and car tires for soilless cultivation) (Cofie et al. 2006; Buechler et al. 2006; Orsini et al. 2009). The expansion of green areas within the cities favors their microclimate and helps maintain the biodiversity (Konijnendijk and 

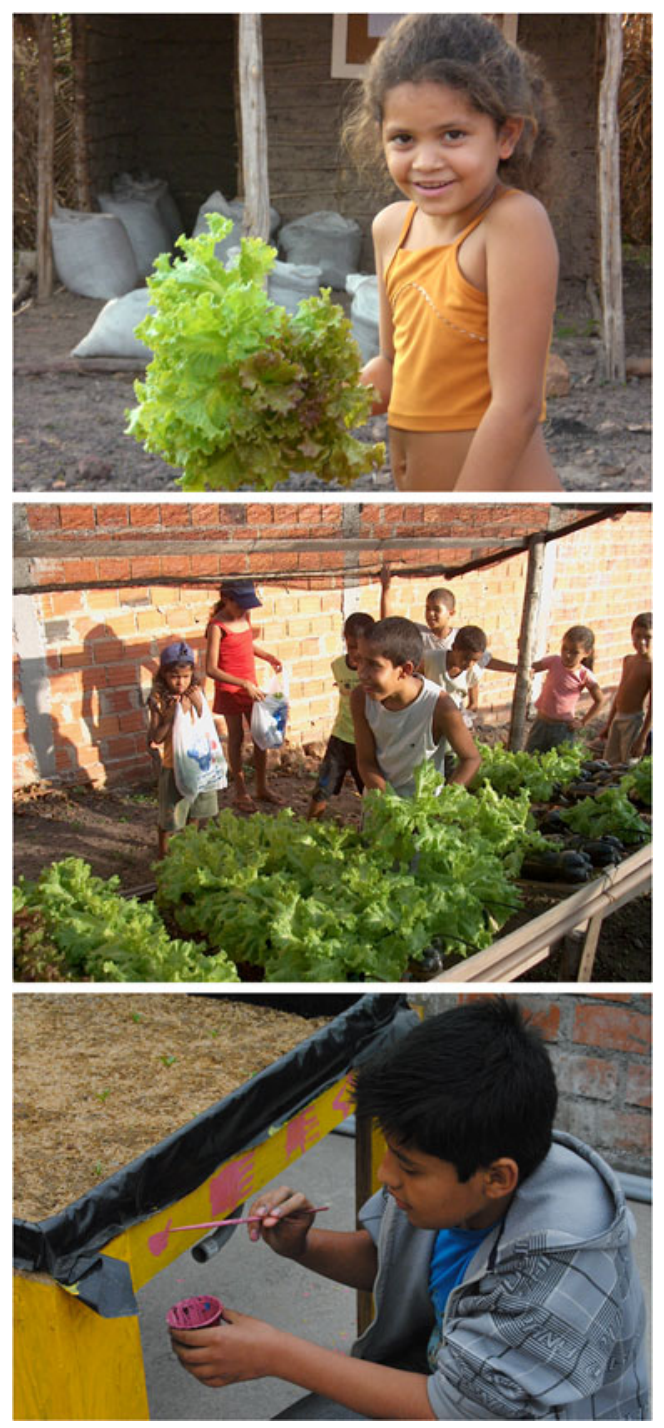

Fig. 1 Children in urban gardens in Teresina, Brazil (top and center) and Monterrey, Lima, Peru (bottom)

Gauthier 2006). The presence of trees, as well as herbaceous species, reduces the suspended dust and the air pollution rate of many compounds, among which the nitrogen dioxide $\left(\mathrm{NO}_{2}\right)$ (Harris and Manning 2010). Urban farming contributes to the reduction of the ecological impact of the cities by both waste recycling (Coffey and Coad 2010), and by reducing emission for transport, packaging, storage, etc., since the production areas are close to the final consumers (Ghosh 2004; de Zeeuw 2010). For instance, compost extracts derived from urban household waste are used for the control of plant diseases in Lomé and Tsévié (Togo), and Dakar (Senegal) (Kessler and Helbig 2001). Furthermore, urban solid waste has been successfully used in urban agriculture in Accra (Ghana) (Asomani-Boateng 2007), also through the use of human decay as an alternative source for plant fertilization (Cofie et al. 2004; WHO 2006). Urban farming indeed allows the requalification of underutilized and degraded lands (Smit et al. 1996), such as those that run below electric lines or along water courses - seasonally affected by flood — or railways, or within industrial areas. In the city suburbs, farming plays the role of connecting the city to the countryside. It should, however, be considered that if not properly managed, it may represent a menace for the water upon and below the ground, for the uses of fertilizers, pesticides, and animal discards (Buechler et al. 2006; Tixier and de Bon 2006). This is of particular concern since the city expansion mostly relegates urban farming within marginal lands, such as wet zones or hills, which are the most sensitive to environmental risks.

The impact and sustainability that urban farming has on the social, economic, and environmental aspects depends on the considered typology and the adopted cropping systems.

\section{Urban horticulture}

As mentioned earlier, urban agriculture includes various production systems among which cropping activities are more common than livestock activities (Zezza and Tasciotti, 2010), and horticulture generally represents the major component. For instance, this system is considered as a typical feature of many West African cities and has been described for Ouagadougou and Bobo Dioulasso, Burkina Faso (Centrès 1996; Freidberg 1997; Eaton and Hilhorst 2003; Dossa et al. 2011); for Cotonou, Benin (Brock and Foeken, 2006); for Lagos, Kano and Port-Harcourt, Nigeria (Ezedinma and Chukuezi 1999; Dossa et al. 2011); for Niamey, Niger (Graefe et al. 2008); for Bamako e Sikasso, Mali (Centrès 1996; Eaton and Hilhorst 2003; Dossa et al. 2011); and for Accra, Ghana (Etuah-Jackson et al. 2001), where it has been identified as the dominant system (Danso et al. 2002) (Fig. 2).

With regard to its nutritional value on the one hand, and its value addition on the other hand, horticultural crop productions provide better livelihoods and additional incomes to all major stakeholders involved in the horticulture value chain (Table 6). Fruit and vegetable crops, if compared to other food crops (e.g., grains), have a much higher yield potential, up to $50 \mathrm{~kg} / \mathrm{m}^{2}$ fresh produce per year, depending on cultivated species and technologies adopted (Drescher 2004). Trainer (1995) described the highest relative yield encountered within family gardens and indicated that $230 \mathrm{~m}^{2}$ was the minimum area required to feed one individual. However, quantifying the smallest surface to be cultivated for ensuring family needs may be extremely hard, since it may consistently vary from the species cropped, the water availability, and the level of technology used. For instance, while Nicaragua home kitchen gardens averaged about 2,300 $\mathrm{m}^{2}$ of land (Méndez et al. 2001), in NorthEast Brazil, household needs could be satisfied with a simplified soilless garden as little as $18 \mathrm{~m}^{2}$ (Orsini et al. 2009). 
Fig. 2 Urban gardens in Ouagadougu, Burkina faso (top), Teresina, Brazil (center left), Abidjan, Ivory Coast (center right), and Lubumbashi (bottom)
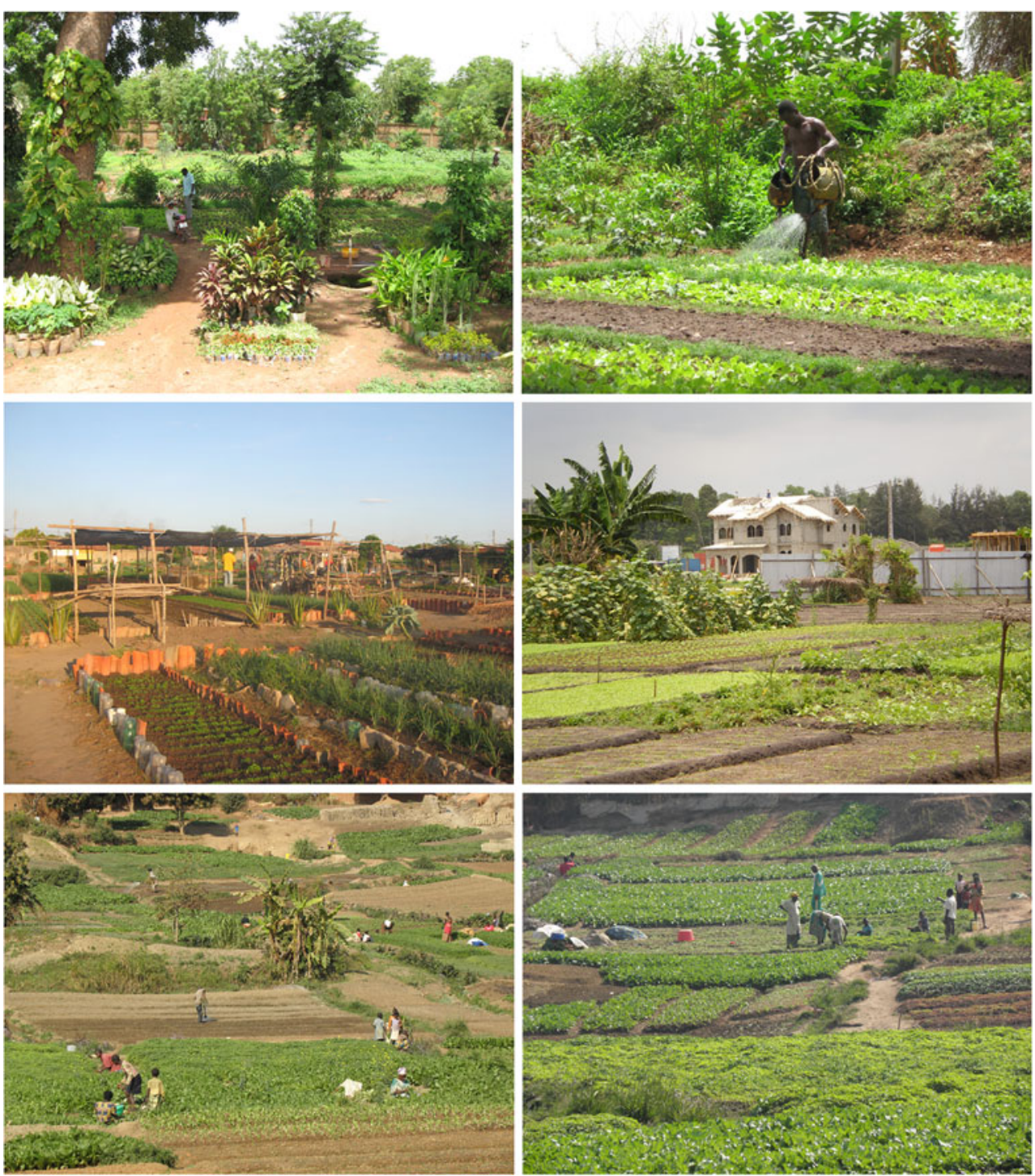

Urban horticulture may include all fruit and vegetable food crops (including roots, tubers, tree nuts, aromatic plants, and mushrooms) or medicinal and ornamental species (Table 7). Therefore, the adopted crop production systems are strongly related to the local culture and traditions. In general, within cities it is preferred to grow short cycle and highly perishable crops, while peri-urban areas are mostly dedicated to medium or long cycle crops and orchards.
Urban and peri-urban farming is substantially different from rural agriculture regarding two dimensions: land and human resources. Land availability represents the highest limiting factor to production in and around cities. Therefore, sustainable intensification of crop production (more than four harvests per year) and cultivation of high value crops are recommended in the cities (Table 8) (de Bon et al. 2010). However, such an intensification requires labour that also
Table 6 Household income of farmers and sellers per week in Kumasi, Ghana, originated from vegetable sale (Drechsel et al. 2006, modified)

${ }^{\mathrm{a}}$ The interval reflects seasonal fluctuations

\begin{tabular}{|c|c|c|c|c|}
\hline & \multirow[t]{2}{*}{ Farmers } & \multicolumn{3}{|l|}{ Sellers } \\
\hline & & Wholesale & Retail & Street vendors \\
\hline Number of observation & 62 & 54 & 190 & 30 \\
\hline Main household composition (adults plus children) & 4.7 & 5.2 & 4.6 & 7.1 \\
\hline Mean family income (US\$/week) & $32-39^{\mathrm{a}}$ & $124-152$ & $23-44$ & 45 \\
\hline Income derived by vegetable marketing (\%) & $53-60$ & $65-70$ & $40-55$ & 50 \\
\hline
\end{tabular}


Table 7 Horticultural plants cultivated in urban areas of East and Southeast Asia

\begin{tabular}{|c|c|}
\hline Vegetables & Aromatic and flowering plants \\
\hline Amaranth, Amaranthus & Agathi, Sesbania grandiflora, \\
\hline Beans, Phaseolus vulgaris & Basil, Ocimum basilicum \\
\hline Broccoli, Brassica oleracea var. italica & Chives, Allium schoenoprasum \\
\hline Cabbage, Brassica oleracea var. capitata & Horseradish, Armoracia rusticana \\
\hline Cassava leaves, Manihot esculenta & Indian borage, Plectranthus amboinicus \\
\hline Cauliflower, Brassica oleracea var. botrytis & Kohlrabi, Brassica oleracea var. gongylodes \\
\hline Chinese cabbage, Brassica rapa var. pekinensis & Lemon grass, Cymbopogon citratus \\
\hline Chinese mustard, Brassica juncea var. rugosa & Mustard, Brassica compestris \\
\hline Choy sum, Brassica rapa var. para-chinensis & Peppers, Genus Schinus \\
\hline Cucumber, Cucumis sativus & Perilla, Perilla frutescens \\
\hline Eggplant, Solanum melongena & Roselle, Hibiscus sabdariffa \\
\hline French bean, Phaseolus vulgaris & Tuberose, Polianthes tuberosa \\
\hline \multicolumn{2}{|l|}{ Garlic, Allium sativum } \\
\hline \multicolumn{2}{|l|}{ Gourd, Genus Cucurbita } \\
\hline \multicolumn{2}{|l|}{ Indian mustard (Chinese mustard), Brassica juncea } \\
\hline \multicolumn{2}{|l|}{ Jaxatu (African eggplant), Solanum aethiopicum } \\
\hline \multicolumn{2}{|l|}{ Kangkong (water spinach), Ipomoea aquatica } \\
\hline \multicolumn{2}{|l|}{ Leek, Allium ampeloprasum } \\
\hline Lettuce, Lactuca sativa & Fruits \\
\hline Lotus, Nelumbo nucifera & Banana, Genus Musa \\
\hline Melindjo, Gnetum gnemon & Melon, Cucumis melo \\
\hline Mung bean (green gram), Phaseolus aureus, Vigna radiata & Orange, Citrus sinensis \\
\hline Okra, Hibiscus esculentus & Papaya, Carica papaya \\
\hline Onion, Allium сера & Peach, Prunus persica \\
\hline Pak choy, Brassica rapa var. chinensis & Pineapple, Ananas comosus \\
\hline Palak, Beta vulgaris & Strawberry, Genus Fragaria \\
\hline \multicolumn{2}{|l|}{ Pea, Pisum sativum } \\
\hline \multicolumn{2}{|l|}{ Potato, Solanum tuberosum } \\
\hline \multicolumn{2}{|l|}{ Squash, Cucurbita maxima } \\
\hline \multicolumn{2}{|l|}{ Sweet pea, Lathyrus odoratus } \\
\hline \multicolumn{2}{|l|}{ Sweet pepper, Capsicum anпuит } \\
\hline Snow pea, Pisum sativum var. saccharatum & Ornamental plants \\
\hline Tomato, Lycopersicon esculentum & Bougainvillea (Genus) \\
\hline Water morning glory (water convolvolus), Ipomea aquatica & Chrysanthemum (Genus) \\
\hline Wheat, Triticum aestivum & Kumquat, Genus Fortunella \\
\hline Yardlong bean, Vigna unguiculata var sesquipedalis & Rose, Genus Rosa \\
\hline
\end{tabular}

becomes limiting in skill and availability: Many urban household members have other activities in competition with farming (Temple and Moustier 2004). The choice of horticultural crops is also determined by the fact that, as compared to other agricultural activities, horticulture presents a more efficient use of the natural resources, such as soil and water (Drescher 2004). Referring to soil and water availability, urban horticulture can be classified into three categories (Drescher and Iaquinta 1999):

- Intensive horticultural systems, with the use of advanced cropping technologies (e.g., localised irrigation and soilless systems), including small-medium scale nurseries
- Mini- or microgardens (also using simplified soilless systems) for the production of vegetables, mushrooms, or cash crops (such as ornamentals, exotic, aromatic, and medicinal plants) (FAO 1995)

- Community gardens, where the land is provided by the local administrations and is subdivided into individual plots of some hundreds square meters each.

Urban horticulture is generally encouraged and promoted in developing countries for the important role it plays in contributing to food and nutrition security, generating income, and creating employment (Weinberger and Lumpkin 2005). It provides the opportunity, especially for the poorest urban 
Table 8 Revenue generated in different farming systems in Kumasi, Ghana (Danso et al. 2002, modified)

\begin{tabular}{|c|c|c|c|c|c|}
\hline \multirow{2}{*}{$\begin{array}{l}\text { Location where the activity } \\
\text { takes place }\end{array}$} & \multirow[t]{2}{*}{ Cropping system } & \multirow[t]{2}{*}{ Cropping season } & \multirow[t]{2}{*}{ Farm size (ha) } & \multicolumn{2}{|c|}{ Net income (US\$) } \\
\hline & & & & per ha/year & per farm/year \\
\hline Rural or peri-urban & Corn or corn/cassava (no irrigation) & Yearly & $0.5-0.9$ & $350-550$ & $200-450$ \\
\hline Peri-urban & Horticulture (irrigation) & Dry season & $0.4-0.6$ & $300-350$ & $140-170$ \\
\hline Peri-urban & $\begin{array}{l}\text { Horticulture (irrigation) } \\
\text { Corn and horticulture (no irrigation) }\end{array}$ & $\begin{array}{l}\text { Dry season } \\
\text { Wet season }\end{array}$ & $0.7-1.3$ & $500-700$ & $300-500$ \\
\hline Urban & $\begin{array}{l}\text { Horticulture (leafy veggy, cabbage, onion) } \\
\text { (irrigation) } \\
\text { Horticulture (leafy veggy, cabbage, onion) } \\
\text { (no irrigation) }\end{array}$ & $\begin{array}{l}\text { Dry season } \\
\text { Wet season }\end{array}$ & $0.1-0.2$ & $2,000-8,000$ & $400-800$ \\
\hline
\end{tabular}

dwellers, to produce fruit and vegetables otherwise not accessible for self-consumption. The localization of the gardens near the markets also reduces the need of conditioning and storage infrastructures and reduces post-harvest losses, which can be as high as $30 \%$ (Drescher 2004). In many cities, indigenous leafy vegetables constitute the main production (e.g., Amaranthus spp, Chinese cabbage, leafy cabbage, lettuce, coriander, and chive) (Kahane et al. 2005; Mawois et al. 2011). Since these products are highly perishable — short shelf life-and do not support transportation to long distance, they offer to the urban producers a market niche that is not occupied by the rural production, located far away from to the urban centers (Gockowski et al. 2003). In developing countries, the urban population strongly influences the amount of vegetables (especially leafy veggies) that is exchanged in the markets (Table 9). As a consequence, urban horticulture becomes an ideal complement to the rural production, crucial for the city food system. In
Vietnam, 26 types of vegetables are regularly produced in large quantities within the cities (Jansen et al. 1996). In Hanoi, urban gardens occupy an area above 7,000 ha (Phuong Anh 2000). In Cuba, as a consequence of the American embargo and the resulting food scarcity, the government officially promoted urban production systems from 1999. In Havana, about 26,000 gardens for the self-consumption are found, most of them using organic farming protocols (Moskow 1999; Murphy 1999; Cruz and Medina 2003). In Shanghai (China), the vegetables production cover more than 10,000 ha, and the number of greenhouses grows constantly (Yi-Zhang and Zhangen 2000). In the city of Baguio in the north of Philippines, following a governmental plan for nutrition (Philippines Plan of Action for Nutrition), between 1994 and 1998, 27,000 gardens in schools, 42,000 community gardens, and 1,600,000 family gardens were planned (Gayan 1996). Urban horticulture provided incomes that were much higher than other farm-related activities: a report of the vegetable peri-urban production in Ho Chi Minh (Vietnam) highlighted that the net daily income

Table 9 Rate of urban horticulture contribution to the city supply (source: Moustier and David 1997; Sabel-Koschella et al. 1998; Phuong Anh 2000; Moustier and Danso 2006)

\begin{tabular}{|c|c|c|c|c|c|c|}
\hline Country & City & Leafy veggie & Tomato & Total vegetables & Corn & Banana, plantain \\
\hline Cambodia & Phnom Penh & 100 & $0-50^{\mathrm{a}}$ & n.d. & n.d. & n.d. \\
\hline Cameroon & Yaoundé & 80 & 25 & n.d. & 90 & 60 \\
\hline Congo & Brazzaville & 80 & 20 & 65 & n.d. & n.d. \\
\hline Ghana & Kumasi & 90 & 60 & n.d. & 10 & 15 \\
\hline Guinea-Bissau & Bissau & 90 & 50 & n.d. & n.d. & n.d. \\
\hline Laos & Vientiane & 100 & $20-100^{\mathrm{a}}$ & n.d. & n.d. & n.d. \\
\hline Madagascar & Antananarivo & 90 & n.d. & n.d. & n.d. & n.d. \\
\hline Mauritania & Nouakshott & 90 & 10 & n.d. & n.d. & n.d. \\
\hline Central Africa Republic & Bangui & $80-100^{(1)}$ & 40 & n.d. & n.d. & n.d. \\
\hline Senegal & Dakar & n.d. & n.d. & 60 & n.d. & n.d. \\
\hline Tanzania & Dar es Salaam & n.d. & n.d. & 90 & n.d. & n.d. \\
\hline Vietnam & Hanoi & 70 & $0-75^{\mathrm{a}}$ & $40-80^{\mathrm{a}}$ & n.d. & n.d. \\
\hline
\end{tabular}

n.d. non defined

${ }^{\text {a }}$ According to the season 
from a vegetable-grown hectare was equal or higher than twofold as compared to rice, and allowed employment levels that were at least five times higher (Jansen et al. 1996).

\section{Factors that affect development and diffusion of urban horticulture}

\subsection{Apparent consumption}

In developing countries, and particularly in those classified as "low-income" and "low-income with food deficit," per capita vegetable consumption is generally low and does not meet the WHO/FAO minimum recommended intakes of $400 \mathrm{~g}$ of fruits and vegetables per day or $150 \mathrm{~kg} /$ year (Tables 10-11). Differences among these countries (found mainly in Africa, Latin America, and Southeast Asia) and the industrialized ones are well defined, especially when considering the Mediterranean countries, traditionally with higher consumption rates. The highest per capita consumptions per year in 2009 was $244 \mathrm{~kg}$ in Greece, $157 \mathrm{~kg}$ in Italy, $155 \mathrm{~kg}$ in Spain, $122 \mathrm{~kg}$ in USA, $102 \mathrm{~kg}$ in Japan, $98 \mathrm{~kg}$ in Australia, $93 \mathrm{~kg}$ in France, $93 \mathrm{~kg}$ in Germany, and $89 \mathrm{~kg}$ in UK (FAOSTAT 2012). Interestingly, although national campaigns for enhancing vegetable consumptions have been taken over in the last decade (e.g., Five-a-Day in USA, UK, and Germany, or "Go for 2 and 5 " in Australia), consumption has not increased. Furthermore, the aggregated figures do not highlight the differences that are found among different areas/regions or the population classes in the selected countries. For instance, from the data of the Brazilian Institute of Geography and Statistic (IBGE 2004), it can be observed how vegetable consumption varies significantly among the main geographical regions in which the country is subdivided (Table 12). In the poorest regions (North and Northeast of Brazil), the vegetable and fruit consumption is generally lower as compared to richer regions of Southeast and South, in particular. In the former, vice versa, much more cassava flour - considered the bread of the poor - is consumed. In the North and the South, moreover, a great rate of these products is self-produced. The consumption-diversification becomes even clearer when analyzing different social classes (Table 13). While the consumption of grains (mainly rice), legumes (mainly cowpea), and cassava flour decreases as the income increases - these foods represent the basic diet of the Brazilian population - the fruit and vegetable share increases. Moreover, the consumption in cities is much lower as compared to rural areas, where selfproduction strongly influences their presence in the diet (Table 14). A similar trend is found in Bangladesh (Ali 2000), while in Vietnam, a greater consumption of vegetables is found in cities as compared to rural areas (Lam and Khoi 1999). In these countries, although the vegetable consumption appear to be extremely low, urban horticulture is stimulated and sustained by the demand of the city markets, mainly as a consequence of the increased demand of the richer classes. Such a statement is, however, not easy to illustrate with data since most of these markets are informal (Goossens 1997) (Fig. 3), and most of the traditional horticultural food crops are poorly considered in national statistics (FAO 2003).

\subsection{Access to natural resources and labor}

Cities in developing countries are rapidly growing, with higher requirement of building areas and consequently increase in the land value. In this context, land access for the urban farmers becomes quite difficult and represents the

Table 10 Yearly per capita consumption of vegetables in low-income and low-income-food deficit Countries in 2009 (source: FAOSTAT 2012)

\begin{tabular}{|c|c|}
\hline Vegetable consumption & Countries \\
\hline$>125 \mathrm{~kg} /$ year per-capita $(>340 \mathrm{~g} /$ day per-capita) & $\begin{array}{l}\text { China, Belarus, Egypt, Bosnia-Herzegovina, Albania, Dem. Rep. Korea (North Korea), } \\
\text { Kyrgyzstan, Azerbaijan, Kazakhstan, Turkmenistan, Laos, Morocco, Uzbekistan, } \\
\text { Armenia, Syria, Tajikistan }\end{array}$ \\
\hline $100-125 \mathrm{~kg} /$ year per-capita (275-340 g/day per-capita) & Cameroon, Lithuania, Republic of Moldova ${ }^{a}$ \\
\hline 75-100 kg/year per-capita (205-275 g/day per-capita) & Myanmar (Burma) $)^{\mathrm{a}}$, Nepal, Vietnam ${ }^{\mathrm{a}}$ \\
\hline \multicolumn{2}{|c|}{ FAO vegetable recommended intake $=75 \mathrm{~kg} /$ year per-capita $(205 \mathrm{~g} /$ day per capita $)$} \\
\hline $50-75 \mathrm{~kg} /$ year per capita (137-275 g/day per capita) & $\begin{array}{l}\text { India, Georgia, Cabo Verde, Djibouti, Philippines, Mali, Nigeria, Sudan, Kiribati, } \\
\text { Sao Tome and Principe, Senegal, Vanuatu }\end{array}$ \\
\hline $25-50 \mathrm{~kg} /$ year per capita $(68-137 \mathrm{~g} /$ day per capita) & $\begin{array}{l}\text { Benin, Niger, Sierra Leone, Guinea, Kenya, Ivory Coast, Sri Lanka, Burundi, Ghana, } \\
\text { Pakistan, Cambodia, Yemen, Gambia, Honduras, Ecuador, Indonesia, Dem. Rep. } \\
\text { Congo (Zaire), Congo, Bangladesh, Tanzania, Mauritania, Mongolia, Uganda, } \\
\text { Zambia, Rwanda }\end{array}$ \\
\hline$<25 \mathrm{~kg} /$ year per capita $(<68 \mathrm{~g} /$ day per capita) & $\begin{array}{l}\text { Haiti, Liberia, Angola, Timor Leste, Togo, Swaziland, Malawi, Madagascar, Burkina } \\
\text { Faso, Central African Republic, Lesotho, Solomon Islands, Guinea-Bissau, Ethiopia, } \\
\text { Chad, Zimbabwe, Comoros, Nicaragua, Eritrea, Mozambique }\end{array}$ \\
\hline
\end{tabular}

${ }^{\mathrm{a}}$ Low-income Countries (per capita GNI $<\$ 745$ in 2001) 
Table 11 Yearly per capita consumption of vegetables in the other developing countries in 2009 (source: FAOSTAT 2012)

\begin{tabular}{|c|c|}
\hline Vegetable consumption & Countries \\
\hline$>125$ kg/year per-capita (>340 g/day per capita) & $\begin{array}{l}\text { Lebanon, Turkey, United Arab Emirates, Lybia, Korea (South Korea), Tunisia, } \\
\text { Kuwait, Iran, Palestine, Maldives, Cuba, Algeria }\end{array}$ \\
\hline $100-125 \mathrm{~kg} /$ year per capita (275-340 g/day per capita) & Bahamas, Cyprus, Latvia \\
\hline $75-100 \mathrm{~kg} /$ year per capita $(205-275 \mathrm{~g} /$ day per capita) & Barbados, Bermuda, Saudi Arabia, Jordan, Jamaica, Dominica, Chile \\
\hline \multicolumn{2}{|c|}{ FAO vegetable recommended intake $=75 \mathrm{~kg} /$ year per capita $(205 \mathrm{~g} /$ day per capita) } \\
\hline $50-75 \mathrm{~kg} /$ year per capita (137-275 g/day per capita) & $\begin{array}{l}\text { Antigua and Barbuda, Brazil, Guyana, Argentina, Seychelles, Brunei, French } \\
\text { Polynesia, Mauritius, Dutch Antilles, Saint Vincent and Grenadines, Mexico, } \\
\text { Paraguay, New Caledonia, Belize, El Salvador, Venezuela, Uruguay, Perù, Guatemala }\end{array}$ \\
\hline $25-50 \mathrm{~kg} /$ year per capita (68-137 g/day per capita) & $\begin{array}{l}\text { Bolivia, Saint Kitts and Nevis, Costa Rica, Gabon, Thailand, Fiji, Dominican Rep., } \\
\text { Colombia, Suriname, Grenada, Malaysia, Botswana, Trinidad and Tobago, } \\
\text { Saint Lucia, Namibia, Panama }\end{array}$ \\
\hline$<25 \mathrm{~kg} /$ year per capita $(<68 \mathrm{~g} /$ day per capita) & Samoa \\
\hline
\end{tabular}

most important limiting factor for their activity (Tixier and de Bon 2006; UN-HABITAT 2008a). Consistently, producers often occupy marginal lands with low fertility that, other than limiting the productivity, strongly reduce the choice among species to be cultivated. The uncertainty of land availability also limits the choice of cultivated species to short-cycle crops (e.g., leafy vegetables) and the practices for restoring soil fertility in order to ensure short-term results at the expenses of medium-long term strategies.
Water availability is often limited; therefore, its use should be improved. Drip irrigation including simplified systems would be appropriate in this context; however, their use is very limited so far (Tixier and de Bon 2006).

The productivity of market gardens varies significantly in different contexts and also in relation to the working conditions of the farming households. When producers find employment, most of the time temporary, in other sectors than agriculture (mainly in industries, services, or administrations),
Table 12 Yearly food supply/ consumption of plant derivates per household: Brazil and "macro Regions."
2002-2003 mean values. In brackets, the percentage of nonmonetary supply (mainly selfproduction) (source: IBGE 2004)

\begin{tabular}{|c|c|c|c|c|c|c|}
\hline \multirow[t]{3}{*}{ Plant-based products } & \multicolumn{6}{|c|}{ Yearly consumption per household $(\mathrm{kg})$} \\
\hline & \multirow[t]{2}{*}{ Brazil } & \multicolumn{5}{|c|}{ Great regions } \\
\hline & & North & Northeast & Southeast & South & Central-west \\
\hline Cereals & $\begin{array}{l}35.5 \\
(6.2 \%)\end{array}$ & $\begin{array}{l}35.6 \\
(11.3 \%)\end{array}$ & $\begin{array}{l}34.4 \\
(8.7 \%)\end{array}$ & $\begin{array}{l}36.7 \\
(5.3 \%)\end{array}$ & $\begin{array}{l}28.8 \\
(3.0 \%)\end{array}$ & $\begin{array}{l}46.8 \\
(3.0 \%)\end{array}$ \\
\hline Legumes & $\begin{array}{l}12.9 \\
(12.4 \%)\end{array}$ & $\begin{array}{l}10.2 \\
(7.9 \%)\end{array}$ & $\begin{array}{l}17.9 \\
(15.1 \%)\end{array}$ & $\begin{array}{l}11.5 \\
(10.9 \%)\end{array}$ & $\begin{array}{l}9.8 \\
(15.6 \%)\end{array}$ & $\begin{array}{l}10.3 \\
(1.3 \%)\end{array}$ \\
\hline Vegetables & $\begin{array}{l}29.0 \\
(9.8 \%)\end{array}$ & $\begin{array}{l}19.7 \\
(23.0 \%)\end{array}$ & $\begin{array}{l}22.4 \\
(5.1 \%)\end{array}$ & $\begin{array}{l}32.4 \\
(4.5 \%)\end{array}$ & $\begin{array}{l}39.3 \\
(24.2 \%)\end{array}$ & $\begin{array}{l}23.3 \\
(8.6 \%)\end{array}$ \\
\hline Leaf & $\begin{array}{l}2.5 \\
(15.1 \%)\end{array}$ & $\begin{array}{l}1.9 \\
(20.3 \%)\end{array}$ & $\begin{array}{l}1.4 \\
(3.5 \%)\end{array}$ & $\begin{array}{l}2.7 \\
(6.9 \%)\end{array}$ & $\begin{array}{l}4.5 \\
(36.9 \%)\end{array}$ & $\begin{array}{l}2.1 \\
(7.6 \%)\end{array}$ \\
\hline Fruits & $\begin{array}{l}13.4 \\
(6.0 \%)\end{array}$ & $\begin{array}{l}9.3 \\
(13.8 \%)\end{array}$ & $\begin{array}{l}12.3 \\
(4.7 \%)\end{array}$ & $\begin{array}{l}15.2 \\
(3.0 \%)\end{array}$ & $\begin{array}{l}13.3 \\
(15.0 \%)\end{array}$ & $\begin{array}{l}11.8 \\
(6.6 \%)\end{array}$ \\
\hline Roots, tubers, etc. & $\begin{array}{l}13.1 \\
(12.6 \%)\end{array}$ & $\begin{array}{l}8.5 \\
(33.8 \%)\end{array}$ & $\begin{array}{l}8.7 \\
(5.8 \%)\end{array}$ & $\begin{array}{l}14.5 \\
(5.6 \%)\end{array}$ & $\begin{array}{l}21.6 \\
(27.2 \%)\end{array}$ & $\begin{array}{l}9.4 \\
(11.3 \%)\end{array}$ \\
\hline Fruits & $\begin{array}{l}24.5 \\
(7.4 \%)\end{array}$ & $\begin{array}{l}17.5 \\
(16.1 \%)\end{array}$ & $\begin{array}{l}20.0 \\
(6.4 \%)\end{array}$ & $\begin{array}{l}27.6 \\
(4.6 \%)\end{array}$ & $\begin{array}{l}31.0 \\
(14.0 \%)\end{array}$ & $\begin{array}{l}17.4 \\
(4.7 \%)\end{array}$ \\
\hline Flour & $\begin{array}{l}13.1 \\
(6.1 \%)\end{array}$ & $\begin{array}{l}36.2 \\
(17.5 \%)\end{array}$ & $\begin{array}{l}17.1 \\
(5.8 \%)\end{array}$ & $\begin{array}{l}5.4 \\
(0.3 \%)\end{array}$ & $\begin{array}{l}19.2 \\
(0.6 \%)\end{array}$ & $\begin{array}{l}5.4 \\
(0.3 \%)\end{array}$ \\
\hline Cassava & 7.8 & 33.8 & 15.3 & 1.4 & 1.0 & 1.4 \\
\hline Wheat & 5.1 & 2.2 & 1.5 & 3.7 & 18.0 & 3.9 \\
\hline
\end{tabular}


Table 14 Yearly food supply/ consumption of plant derivates per household and percentage of nonmonetary supply (mainly self-production) in urban and rural areas in Brazil
2002-2003 mean values (source: IBGE 2004)

\begin{tabular}{|c|c|c|c|c|}
\hline \multirow[t]{2}{*}{ Plant-based products } & \multicolumn{2}{|c|}{ Yearly consumption per household $(\mathrm{kg})$} & \multicolumn{2}{|c|}{ Nonmonetary supply (\%) } \\
\hline & Urban area & Rural area & Urban area & Rural area \\
\hline Cereals & 31.4 & 55.5 & 5.6 & 26.5 \\
\hline Legumes & 10.7 & 23.5 & 6.9 & 46.7 \\
\hline Vegetables & 28.4 & 31.7 & 5.5 & 53.1 \\
\hline Leaf & 2.4 & 2.8 & 7.7 & 67.6 \\
\hline Fruits & 13.7 & 11.9 & 5.0 & 42.1 \\
\hline Roots, tubers, etc. & 12.3 & 17.0 & 5.6 & 58.5 \\
\hline Fruits & 25.7 & 18.5 & 6.0 & 56.3 \\
\hline Flour & 9.5 & 30.2 & 5.9 & 21.5 \\
\hline Cassava & 5.1 & 20.8 & 9.2 & 30.1 \\
\hline Wheat & 4.2 & 9.2 & 2.1 & 2.4 \\
\hline
\end{tabular}

gardening becomes a part-time activity. In these conditions, production often becomes scattered and mismanaged.

\subsection{Environmental pollution}

Cities have in most cases highly polluted air, soil, and water. The best bet for the urban horticulturist is to grow plants under strong stresses, determined by high $\mathrm{SO}_{2}, \mathrm{NO}_{2}$, and ozone atmosphere concentrations, caused by the intense vehicular traffic (Agrawal et al. 2003), and the soil contamination with heavy metals, hydrocarbons, and pesticide residuals. Another critical point is the achievement of a healthy product under these conditions. The greater risks, not only for the consumers but also for the producers who get in contact with contaminated material (e.g. from any waste, including non composted animal dejections), are related to heavy metal, pesticides, and microbiological contaminations (Buechler et al. 2006; Cofie et al. 2006). The issue of polluted urban environment is also the risk to contaminate what has been produced safe: Poor storage, transport, and handling practices are often worst than producing ones, and closer to the consumer's plate (Onyango et al. 2008; Karanja et al. 2010). The latest results highlight the need to sensitize consumers and not only producers about food safety.

The concern of heavy metals mainly occur when cultivations are placed in former industrial areas or nearby factories (Pandey and Pandey 2009), on lands irrigated with water and/or, on solid contaminated industrial or mining wastes (Mapanda et al. 2007). Avoiding cultivation in these contexts is an option to mitigate the risk of contamination. Indeed, accumulation of heavy metals in the edible parts of the plant varies among species and cultivars. As a general rule, leafy vegetables are stronger accumulators as compared to fruit vegetables or vegetables cultivated for their seeds, and therein, in critical contexts cultivation could satisfactorily be re-addressed to the latter (Gianquinto and Pimpini 1991; Odai et al. 2008; Säumel et al. 2012).
Table 13 Yearly food supply/ consumption of plant derivates per household: Brazil, classification by income

Mean values of 2002-2003

(source: IBGE 2004)

\begin{tabular}{|c|c|c|c|c|c|c|}
\hline \multirow[t]{2}{*}{ Plant based products } & \multicolumn{6}{|c|}{ Yearly consumption per household $(\mathrm{kg})$} \\
\hline & $\leq 400 \mathrm{R} \$$ & $\begin{array}{l}>400 \mathrm{RS} \\
\leq 600 \mathrm{R} \$\end{array}$ & $\begin{array}{l}>600 \mathrm{R} \$ \\
\leq 1,000 \mathrm{R} \$\end{array}$ & $\begin{array}{l}>1,000 \mathrm{R} \$ \\
\leq 1,600 \mathrm{R} \$\end{array}$ & $\begin{array}{l}>1,600 \mathrm{R} \$ \\
\leq 3,000 \mathrm{R} \$\end{array}$ & $>3,000 \mathrm{R} \$$ \\
\hline Cereals & 36.8 & 41.1 & 38.4 & 37.2 & 32.2 & 26.7 \\
\hline Legumes & 15.0 & 14.5 & 13.7 & 12.6 & 10.3 & 11.3 \\
\hline Vegetables & 15.7 & 22.4 & 25.7 & 31.2 & 36.2 & 42.3 \\
\hline Leaf & 1.0 & 1.5 & 2.1 & 2.6 & 3.1 & 4.7 \\
\hline Fruits & 7.9 & 11.6 & 11.8 & 13.9 & 15.6 & 19.8 \\
\hline Roots, tubers, etc. & 6.8 & 9.3 & 11.8 & 14.8 & 17.4 & 17.8 \\
\hline Fruits & 11.1 & 14.1 & 18.6 & 24.5 & 33.4 & 45.9 \\
\hline Flour & 17.4 & 17.8 & 14.9 & 11.7 & 10.3 & 6.7 \\
\hline Cassava & 14.2 & 13.7 & 8.5 & 5.6 & 3.7 & 2.2 \\
\hline Wheat & 3.2 & 4.0 & 6.2 & 5.8 & 6.4 & 4.1 \\
\hline
\end{tabular}


Fig. 3 Street markets along Yamoussoukro-Gagnoa highway, Ivory Coast (top left), Yenanchaung, Myanmar (top right and center), and Karatina, Kenya (bottom)
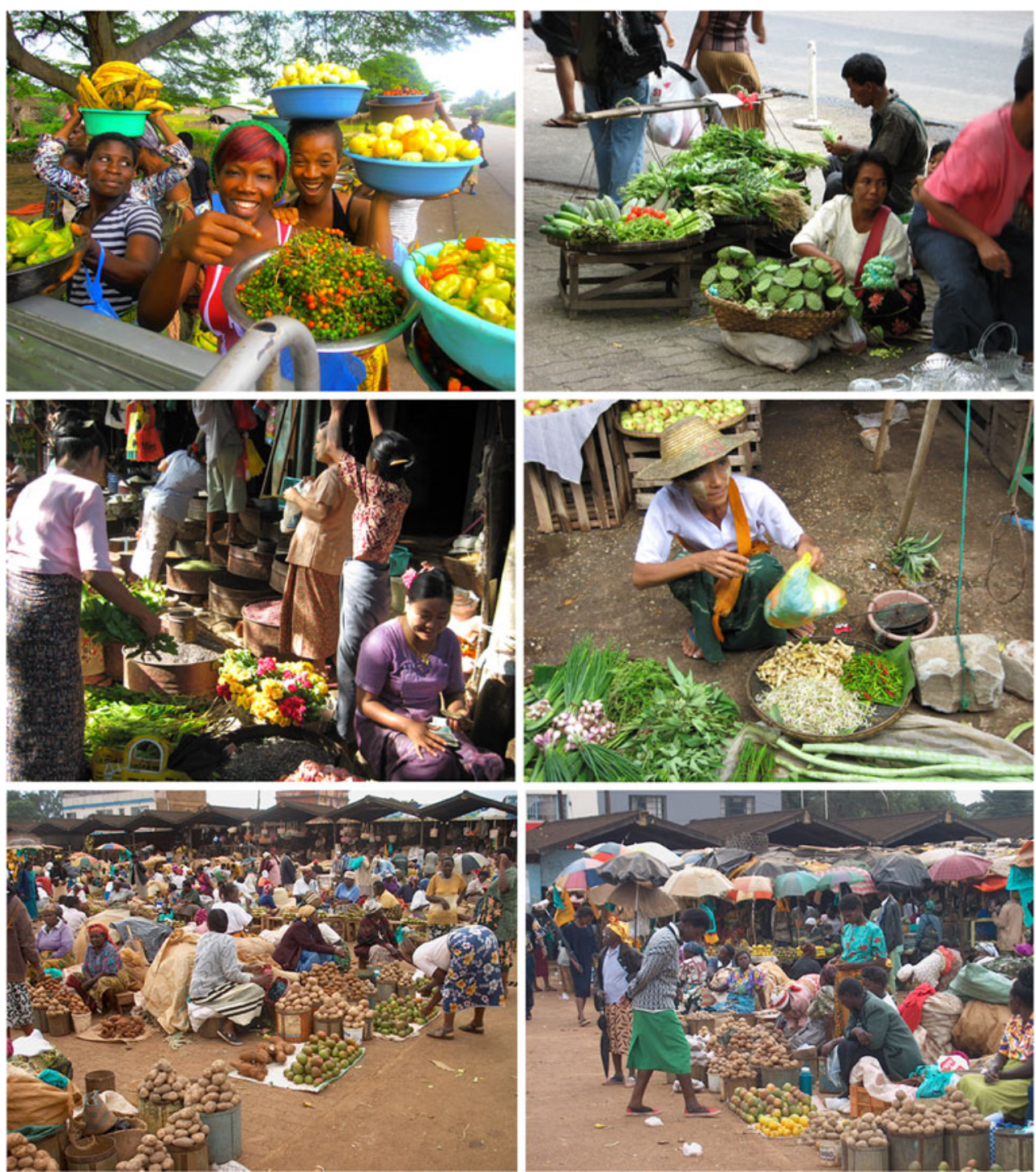

Pesticide residuals in the food products are caused by both the phytochemicals adopted during the cropping cycle and contaminated soils or waters. This remains an important problem in countries where pesticides that are already banned elsewhere are till commercialized. Toxic residuals tend to accumulate in the reserve organs of the plant, such as tubers and roots (Tixier and de Bon 2006).

Finally, the microbiological risk-bacteria, viruses, protozoa, etc. - and the consequential risks for producers and consumers occur when using contaminated water or organic manures inopportunely processed.

\subsection{Climatic conditions}

The "heating island" effect found in cities, as compared to the countryside, is particularly critical in the tropical environment, where also meso- and macrothermal species are hardly grown during the warmest seasons (Jonsson, 2004).
In Teresina, capital city of the Brazilian state of Piaui-and one of the most important city of Latin America for the incidence of urban horticulture-situated in the equatorial basin $\left(5^{\circ} 05^{\prime}\right.$ south and $42^{\circ} 48^{\prime}$ west), the minimum daily temperature during the dry season (midJune to the end of December) ranges from 20 to $30{ }^{\circ} \mathrm{C}$, while the maximum is always higher than $35{ }^{\circ} \mathrm{C}$, and goes above $40{ }^{\circ} \mathrm{C}$ in the warmest periods (Bastos and de Andrade Júnior 2000). In these months, relative humidity ranges from 30 to $50 \%$ during the day and 50 to $90 \%$ at night. During the rainy season, temperatures, especially at night, are mitigated. However, owing to the extremely intense rainfall and the consequential erosion occurring in cropped lands, cultivation is almost impossible. The city growth has enhanced these phenomena, reducing water drainage, and confining agriculture to marginal areas normally subjected to flooding. In this period, cultivation is usually interrupted. 
In some cities (e.g., in Brazil and Argentina), municipalities are key actors of the urban production, and they are involved in the development of community gardens. In Northeast Brazil, a comanagement model is found where the municipality (prefeitura) and the urban communities collaborate with the following aims (Branco and de Alcântara 2012):

- To recover marginal lands (that would otherwise be illegally occupied or become landfill;

- To improve health and food-security conditions of the consumers, with the use of artesian wells as a water source

- To improve access to food, employment rate and family income of the households involved

- To increase family aggregation and social inclusion, thus reducing child marginalization.

In Teresina, Piauì, nowadays, there are 52 community gardens (hortas comunitárias) managed as mentioned above. They take up about 170 ha of urban area and include the biggest community garden of Latin America the "Horta Comunitária do Grande Dirceu," which lies in an area, below the electric line, $4 \mathrm{~km}$ long.

A survey conducted in 43 out of these 52 gardens (Monteiro and Monteiro 2006) revealed that:

1. The majority of gardeners were women, over 45 years old, migrated from countryside of Piauí.

2. They cultivated the gardens together with their children and partner.

3. The majority of the producers did not attend learning programs related to the garden activity.

4. Seventy to eighty percent of the production was represented by coriander, chive, and lettuce

5. They usually applied pesticides-though in small quantities - to control weeds, pest, and diseases.

6. They self-financed themselves.

7. They sold the products at the garden, earning no more than one minimal salary.

Other important issues regarded the lack of consistent knowledge and skills on:

1. Methods of protection when applying chemicals

2. Alternative and sustainable cropping systems, such as organic agriculture, and techniques to obtain healthy products

3. Methods to preserve soil and water resources.

The study concluded that the low remuneration, which derives from the little crop diversification, the precarious organization and form of sale, and lack of financings, had driven some members of the family to search alternative occupations to complement the family income. The investigation also emphasized that most producers, already being involved in horticulture before, denoted the ability inherent in this type of activity. The authors affirmed consistently that gardeners would require only systematic qualification by the municipality, which should provide courses and/or seminars focused on alternative crops and cropping systems, implementation of organic agriculture, and promotion of sustainable local development. To support these efforts, the Federal "Ministério do Desenvolvimento Social e Combate a Fome" ("Ministry of Social Development and Against Hunger") has funded the Teresina Municipality with more than 1 million and 300 thousand Reais (R\$) to be spent during 2012-14, in order to increase and innovate urban garden production, logistic and marketing through training, new equipment and materials (in particular, tools for irrigation), and to generate income for the beneficiary households (Portal dos Convênios 2012)

\section{Traditional cultivation systems}

Systems adopted in urban horticulture are extremely diversified and, for the sake of this publication, could be classified into four main types.

6.1 Mixed farming systems on a limited acreage first target household consumption and small-scale marketing

These market gardens (usually called family gardens, backyard, or community gardens as well) are usually found in urban areas on lands temporarily unoccupied or dedicated to horticultural activities by the municipality (e.g., community gardens in Brazil, Villas-Boas 2006). In some cases, these are family gardens located in the household courtyard or along the streets. Cultivation occurs in small growing beds, and it is widely diversified, ranging from leafy vegetables and others (beans, carrots, onions, solanaceae, cucurbits, etc.), to grains (e.g. corn, rice), ornamentals, herbs, and fruit trees (e.g., passion fruit, banana, papaya, coconut, avocado, etc.). Intercropping is frequent. Usually, open pollinated cultivars are used; seeds and seedlings are purchased from informal markets. Organic fertilization is common, altogether with crop protection strategies (against rainstorm or excessive radiation), but very competitive due to less and less animal husbandry located in the vicinity. Irrigation techniques are diverse, ranging from infiltration systems (side infiltration or temporary flooding of the beds), to the most common wetting through water cans or buckets. The latter appears to be more efficient, allowing more precise distribution and water use efficiency, but at the same time requires more labor: In the tropical regions, manual irrigation shall be performed two to three times per day what represents about $60 \%$ of the manpower required for vegetable production (Tixier and de Bon 2006). In tropical climates, plant water requirements range from 400 to 
$8001 \mathrm{~m}^{-2}$ for tomato production (about 120 days from transplanting to harvest) and 150 to $3001 \mathrm{~m}^{-2}$ for leafy vegetables with a life cycle of 30-40 days (Tixier and de Bon 2006). In arid and dry climates, water requirements may be higher (up to three- to fourfold), and this also occurs when the adopted irrigation systems are scarcely efficient. Consistently, a primary objective is the improvement of water use efficiency, by the use of drip irrigation or simplified localized irrigation, which allows avoid water contact with the aerial part of the plant - and contributes to the reduction of pest occurrence and microbiological contamination. Such systems may contemplate, as an example, the use of water tanks of 200-250 1 placed at $2 \mathrm{~m}$ height-possibly filled with rainwater collected from roofs-from which a series of irrigation pipes (5-10 $\mathrm{m}$ long) deliver irrigation to the garden. Sand filters (Khosa et al., 2003) can be adopted in order to avoid clogging of the drippers. These systems are particularly useful for urban producers since they do not require high starting capitals (Ghosh 2004).

\subsection{Extensive monocropping systems for both home consumption and market}

Within this class fall those farms that are usually found in the periphery of the city, on lands occupied or owned by the producers (or rented). Generally, no irrigation is provided to the crops, and also the use of both organic and inorganic fertilizers is scarce. As a consequence, the choice of species to grow is oriented to the locally adapted ones (e.g., cassava, yam, sweet potato) or mostly consumed (e.g., corn, rice). A possible example of these systems has been described by Lemeilleur et al. (2003), when addressing banana production systems in the city of Yaoundé (Cameroon). Plantations were generally located along steep slopes, generally unsuitable for settling houses but optimal for plant cultivation (e.g., better sun exposure and water management during the rainy season). These farms were generally 2.5 ha big, representing an equilibrium between the activities that could be carried out by individuals of an household and their food needs. Moreover, although the farm resulted to be subdivided in few smaller gardens, all of them were located within small distances, and transport was one of the main production costs. Major constraints faced in these situations were generally associated to theft of the produce and the scarcity of available agricultural inputs (e.g., pesticides). Similarly, Bhatta and Doppler (2010) documented the main features of monocultural peri-urban systems in Nepal, describing farms located in sloped lands for about $50 \%$ of their surface, mainly producing vegetable crops sold in the nearby markets. However, these systems that previously took advantage of the reduced transport costs as compared to the rural production, nowadays, are losing relevance, since they must compete with the diffuse small-scale production that is encountered within the city.

\subsection{Shifting cultivation systems}

It is also called slash-and-burn systems, representing the basic cropping system found in many tropical regions. They usually occur in areas occupied or rented from the land-owner. In the city borders, they appear as a result of both the migratory flux of the population toward the cities and the enlargement of the city over previously forested lands. They basically consist in a first stage of cutting the forest down in a delimited surface (about $1,000-5,000 \mathrm{~m}^{2}$ ) in the city borders. The vegetation is then burned (for the production of ashes), and successive crops are directly sown with no further soil preparation. In these systems, a great coexistence of bio-diverse species is found, ranging from corn to cassava, beans, rice, okra, various cucurbits, chili pepper, etc. No fertilizers are adopted other than the combustion ashes, and no irrigation is provided. In the first year, production is generally satisfactory (as a consequence of the rapid mineralization of the organic matter and the presence of ashes), while in the following years, productivity decreases more or less rapidly in relation to the soil features and the organic matter degradation (Sanchez 1976). Consistently, after a certain number of years, the cultivation is shifted to allow soil fertility to recover. In the past, the cultivation frequency - expressed as percentage of the length of the cultivation period over the total cycle length (cropping + recovery) - was about $10 \%$ (e.g., cultivated 1 year and recovered for 9 years). Nowadays, the increased urbanization and population growth has increased the values to $50 \%$ and even $70 \%$ (Norman et al. 1995). The ecological and environmental impacts of this cropping intensification without addition of fertilization are marked and the consequences may be extremely negative.

\subsection{Intensive horticultural cropping system on medium- or large-scale farms}

This system is usually conducted in lands owned (or rented) by the producers and assumes the form of real agricultural farms. These farms are located in the peri-urban area, and the production is strongly market-oriented. They can either be specialized in one or few crops (in case of fruits for instance) or produce a high diversity of species (usually the case with vegetables). Farmers make use of improved cultivars, often F1 hybrids or grafted materials, and their technological skill is comparable to the one of farmers in more developed countries, where they often have studied themselves. Agricultural practices are partially mechanized, although the farm still relies on the cheap labor forces. The soil is often amended and fertilized with mineral fertilizers. Irrigation systems are adopted, also with the use of localized irrigation, rain harvesting, and, in some cases, fertigation. These systems are input intensive and may use greenhouses and in some cases soilless cultivation; they also integrate 
pesticides for pest and weed control in prevention programs rather than an IPM approach. However, due to the pressure exerted by both market standards and environmental regulations, "environmentally friendly" production strategies are also very relevant for these production systems.

As presented these typologies of farming systems have several levels of complexity regarding both technologies and agronomic practices adopted for horticultural species. However, even in the most simplified system, the appropriate management of agricultural inputs is a key for producing fresh produce. Its high quality value has to deal with high nutritional value and low risks for the producers, the consumers and the environment. As a general rule, it can be said that the risks of urban horticulture are those usually found in rural condition, although amplified by the proximity and density of the resident population and by the strong artificial context. As a consequence, considering the preventive measures required when utilising agricultural inputs that represent a risk for the human health and the environment, the urban context turns the risks at a higher degree. In addition, the information system in a city gives all actors of the food chain, including local authorities, higher visibility, and also more responsibility.

The use of pesticides including obsolete ones, which are often not registered, represents a high risk for human health. Their use depends on their cost and the higher is the crop value the more expensive would be the cost of management practices. Very often, farmers do not observe the safety delay after treatment and crops can be sprayed with pesticides till a few hours before harvest, even after harvest in some cases where it is considered as "an added value by consumers." In these situations, the pesticides used can be very toxic and content highly persistent products that are being banned in more industrialized agricultural systems. Although there is not a comprehensive description in current literature, several cases have been reported of residue levels higher than the maximum acceptable thresholds in such contexts (Amoa at al. 2006; Midmore and Jansen 2003; Moustier et al. 2006). The problem of the risk is considerable also for the producers that usually use phyto-chemicals inappropriately, without protective measures for them and the environment. One way to reduce these risks is to make available qualified technical assistance for appropriate technology transfer to the production area.

\section{Innovative cropping systems}

New technologies have been developed in order to (1) address the low soil fertility and/or water availability, (2) optimize the cultivation in limited spaces, and, (3) minimize the impact of the horticultural production to the environment and human health. Such technologies have proven to be efficient in addressing these constraints, but need to be integrated into local farming and food systems to have a chance to be adopted. In particular, they need to be associated with knowledge transfer and technical assistance. Some of them use natural substrate and various kinds of compost (e.g., organoponic cultivation), others refer to simplified soilless systems. These highly intensive cropping systems find their application in urban and periurban areas where cultivation space is very scarce and its use very competitive. In highly urbanized contexts, they are found on the rooftop of houses (Kundall 1995; Deesohu Saydee and Ujereh 2003; Shariful Islam 2004; Viney et al. 2011). Rooftops planted with plants also contribute to the house thermal insulation (Eumorphopoulos and Aravantinos 1998) and reduce the energy required for cooling the house (Wong et al. 2003).

\subsection{Organoponics}

Organoponic systems consider the cultivation on organic substrates where soil present low fertility and no chemical is brought. Crops are hosted in containers filled with compost or organic matter of various origins. The adoption of properly composted animal manure has proven to ensure high yields and healthy produce. It was commonly adopted in Venezuela and Cuba (Cruz and Medina 2003; Tixier and de Bon 2006). In Cuba (Fig. 4), this system was promoted and supported by governmental programmes since the 1980s, when the fall of the Soviet block and the more severe sanctions from the USA caused serious concerns on food insecurity (Altieri et al. 1999). Cuban organoponic systems

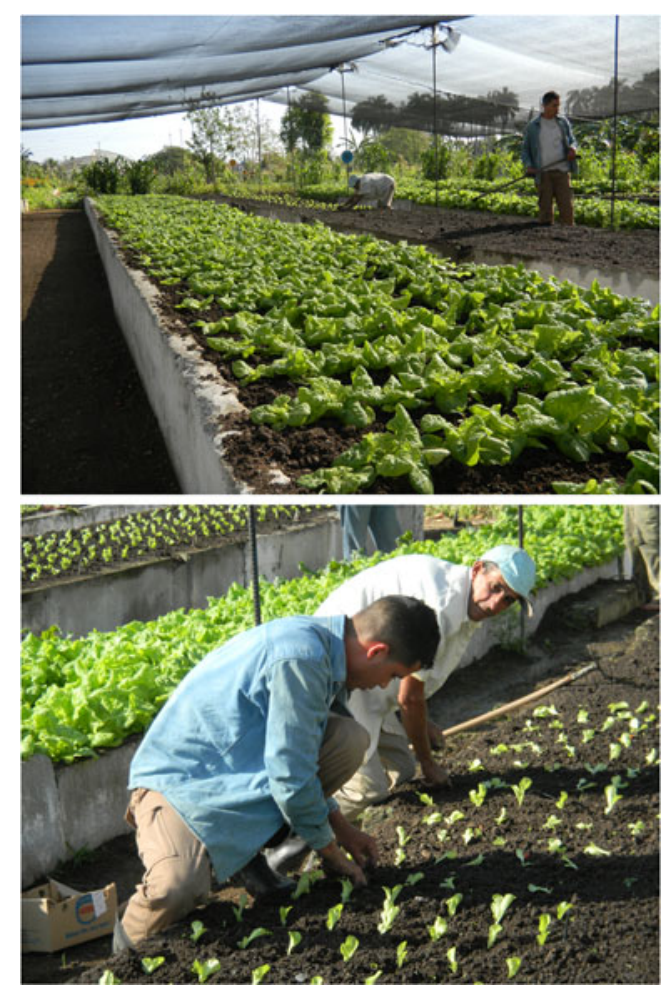

Fig. 4 Organoponic gardens in Cienfuegos, Cuba 
use a mixture of soil and organic matter (residual of the sugar production chain) in measure of 50:50 v/v. These systems provide products for household consumption as well as for school canteens, hospital, and working refectories. They are usually managed by individuals or cooperatives (Novo and Murphy 2000). In Havana, more than 450 organoponic gardens could be found in 1999, out of which about 20 were considered highly productive (providing yield of $16 \mathrm{~kg} \mathrm{~m}^{-2}$ ) (Murphy 1999). More than 200 are still running according to Wikipedia (search at: Organopónicos) and provide the Havana inhabitants with $50 \%$ of their needs in fruits and vegetables. Best gardens were also used for training and dissemination; they are nowadays studied by scientists and extensionists (FAO Greener Cities 2012). These gardens were famous in particular for the diversity in fruits and vegetables produced in the city (Skeffington 2006). These technologies of production are strictly related to ecologically friendly agronomic practices, and particularly to the improvement of fertility through the use of microorganisms and the adoption of integrated and organic control systems (Prain 2006). Cuba is the world leader in the production and use of entomopathogens that are produced in specialized centers and distributed through various channels, including "corner shops" and technical assistance centers (Rosset and Benjamin 1994). It is surprising that such a system has not yet spread elsewhere in the world for its objective benefits, and not only for political reasons like in Caracas, Venezuela. For instance, while in Cuba, organoponics developed following a bottom-up approach in response to the food crisis, in Venezuela, they were introduced through a topdown governmental program and production was constrained by the high atmospheric pollution of the city, as well as to the low interest from the local population. The financial and food price crises will probably attract more attention to this way of promoting "eat local" movement (Israel 2008; Prain 2010).

\subsection{Simplified hydroponic systems}

The diffusion of simplified hydroponic systems is strongly encouraged by the FAO through microgardens, and they are nowadays found in several countries of Africa, Asia, and Latin America (FAO Micro Gardens 2010; Institute of Simplified Hydroponics 2011) (Fig. 5). This term usually includes both the "pure" hydroponic systems (where the roots are submerged in the nutrient solution, e.g., floating system), and systems that consider cultivation on substrates of various nature, watered with nutrient solution. The latter can easily be adopted in diverse climatic and environmental conditions, while the former are difficult to use above certain temperatures for the concentration of oxygen in the nutrient medium is inversely related to the temperature, and consequently, root oxygenation may be affected. The floating system is also discouraged in regions where diseases such as malaria, which is transmitted by mosquitoes, are found because the vectors may lay their eggs in the cultivation tanks (Klinkenberg and Amerasinghe 2006).

The sustainability of hydroponic systems has been reported in several situations and countries (Bradley and Marulanda 2001; Marulanda and Izquierdo 2003; Caldeyro-Stajano 2004; Izquierdo 2007; FAO 2007; Gianquinto et al. 2007a, b; Klinkenberg et al. 2008; Fecondini et al., 2010; Mezzetti et al. 2010; Orsini et al. 2010a, b, c). In Trujillo (Peru), the time for the return of the initial investment was defined in $<1$ year for both substrate and floating systems (Orsini et al. 2010b, c). Similarly, $<1$ year was needed to pay back the initial cost of a Garrafas pet hydroponic system in Teresina (Brazil) (Fecondini et al. 2009; Orsini et al. 2009). In the same study, it was shown how both the quantity and the diversity of vegetables in the diet were improved by participation to a program promoting simplified hydroponics. Nonetheless, it should always be considered that the identification of appropriate technologies to both the financial condition and the skills of the farmers is crucial for the technique to provide appreciable results. At present, these techniques are becoming very popular in several Latin American countries (Rios 2003; Tabares 2003). Experimental trials conducted in Teresina (Brazil) have shown that the mean daily water needs for a lettuce crop grown on a Garrafas PET system (Gianquinto et al. $2007 \mathrm{a}, \mathrm{b})$ are about $2.0-2.51 \mathrm{~m}^{-2}$, as compared to the $10-121 \mathrm{~m}^{-2}$ of the conventional on-soil cultivation (Ferreira da Silva, personal communication). This result is even more relevant when considering that cropping density in soilless cultivation is about twice the density on-soil cultivation (22 and 12-15 plants $/ \mathrm{m}^{2}$, respectively). These figures are consistent with those indicated by Tixier and de Bon (2006) for a closed cycle hydroponic system.

In the simplified hydroponic systems, the critical points are associated with water quality and fertilizer availability. If the available water is saline or contaminated with chemical or biological agents, the system management may become problematic. To avoid such a problem, it is recommended to harvest rain water, characterized by low electrical conductivity as well as low microbial and algae contents. The constraint remains in water storage and investing in a water tank. According to preliminary results, the adoption of waste water instead of using nutrient solution prepared from mineral fertilizers, as suggested by some authors (Mavrogianopoulos et al. 2002), may not be feasible.

The success of hydroponic systems relies much on the nutrient solutions supplied to the plants: their availability in developing countries, their affordability for small-scale gardeners, and their reliability since the users will not buy huge stocks in advance, but a daily or weekly quantity. Ideal and most sustainable situations involve a public institution, like La Molina University in Peru that sells nutrient solutions to growers (Rodríguez-Delfín et al. 2001; La Molina 2012). The Institute of Simplified Hydroponics (www.carbon.org) 
Fig. 5 Simplified soilless systems for home and community gardening in Jeremie, Haiti (top left), Trujillo, Peru (top right), Teresina, Brazil (center), and Abidjan, Ivory Coast (bottom)
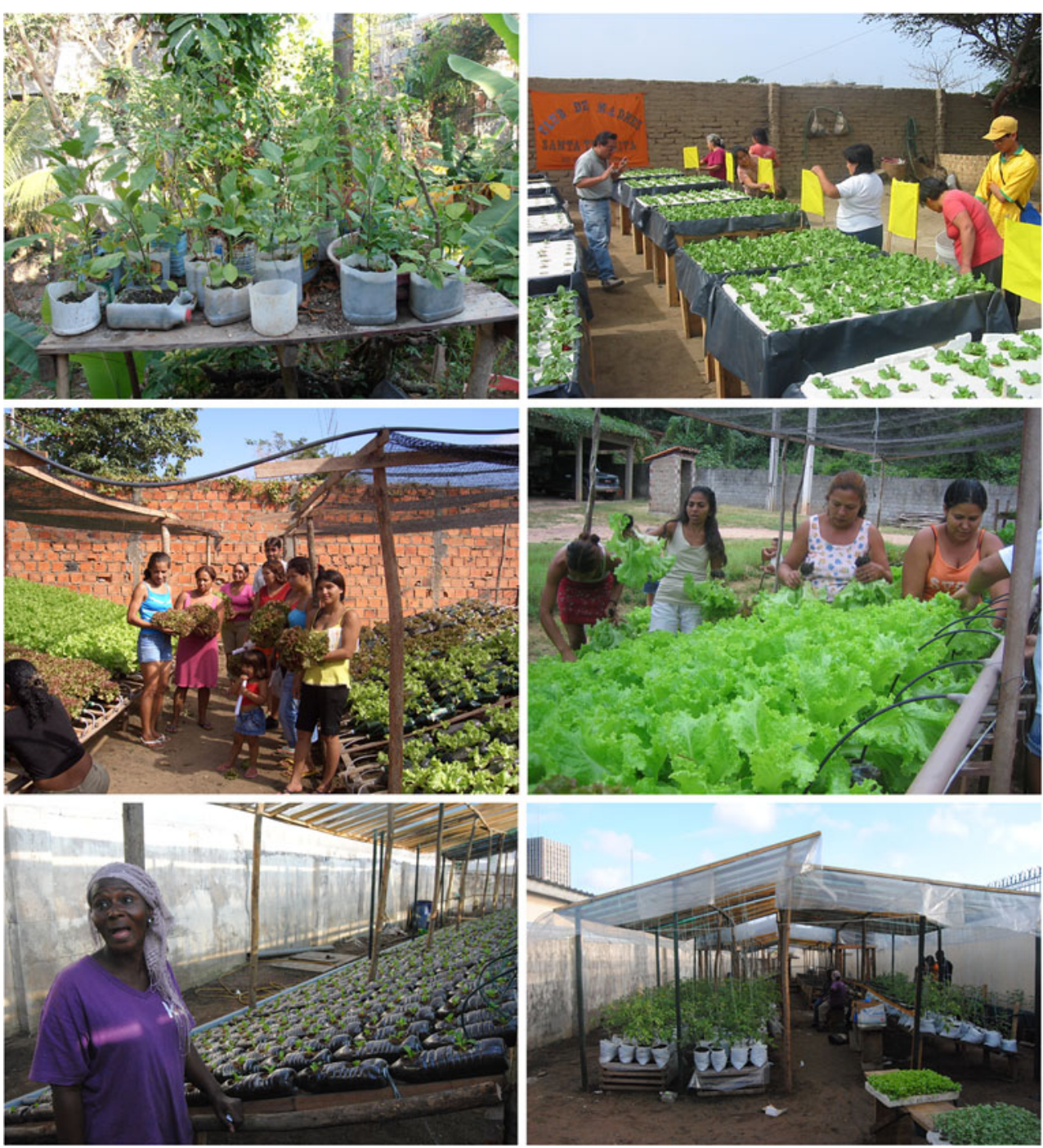

assists horticultural groups in several developing countries (e.g., Afghanistan, India, Peru, Senegal, Venezuela) also providing training courses. Moreover, the Vegetable crops and Urban Horticulture Research Group of the University of Bologna provides assistance, technical training, and manuals on simplified soilless techniques (Orsini et al. 2010b, c) in Peru, Brazil, Mauritania, Ivory Coast, Burkina Faso, and Myanmar.

\section{Conclusions}

In several cities of developing countries, urban horticulture significantly contributes to food and nutrition security of urban dwellers. It is expected that this agricultural activity will gain in recognition for its benefits and services in a near future since towns and cities, especially in the developing world, are growing on an unprecedent scale and rural-urban migration is still on the rise.

The production of fresh fruit and vegetable that can be available also for the poorest population and their subsequent improvement in terms of both food security and health conditions is one of the primary objectives of urban horticulture (Urban Harvest 2011; UWEX 2011). Indeed, other roles of urban horticulture, namely, the (1) socioeconomic (income and employment generation and social integration of the disadvantaged people) (UNDP 1996); (2) cultural, educational, and recreational (mainly for the youngest) (PUVEP 2011); (3) ecological/environmental (maintenance of the biodiversity, waste management and recycling, reduction of the city environmental footprint, improvement of the microclimate, and requalification of marginal and abandoned areas) (ACGA 2011), should also be considered. The current multifunctionality of urban horticulture will become crucial for the sustainability of food city supply in the future, as it is adopted and promoted by the local institutions and governments (Livelihoods Connect 2011; ProHuerta 2011; Prolinnova 2011).

It is estimated that worldwide, about 25-30\% urban dwellers are involved in the agro-food sector. The relevant importance of this subsector has finally attracted the attention of several local authorities who have recently included space 
for horticulture in the urban master plans of their cities (Prain 2010). The availability of horticultural produce, the crop residuals (including water) management and the connection among the different actors involved in the food system are the main aspects that should be considered in the future development of the sector. It is reasonable to expect not only from governmental organizations and local authorities but also from the private sector, the promotion of training and technical assistance for the actors of urban farming, with a special regard to soil and water management, impact practices, farm management, postharvest and marketing, and control of the risks for both human health and the environment.

The urbanized environment is bringing to the front a category of actors that is playing a bigger role every day, also in developing economies: the consumers. Local authorities realize that the consumers are also their electors. Satisfying their needs in terms of food security is therefore becoming a political priority. Human health through food safety and diversified diet is also becoming an urgent issue that mayors and district officers cannot ignore anymore. Urban horticulture will not be driven by production anymore, rather by consumption. The way food and nonfood horticultural produce is grown, handled, traded, and processed before it reaches consumers' plate will be designed by the consumers, and the appropriate technologies and/or food systems will then be adapted and applied. This is where general awareness on the benefits of horticulture as food, and also as economic, cultural, and environmental elements of the society is needed.

Further research should therefore address a better understanding of the relations between plants, city dwellers, and the urban environment, and establish the conditions for permanent upgradable systems able to adapt to an environment that changes day by day.

Acknowledgments The authors are grateful to Wilfried Baudoin at FAO for helpful comments and critical review of an earlier draft. The opinions expressed in this paper are those of the authors and do not necessarily express the views of their respective institutions or organizations.

\section{References}

ACGA (2011) http://www.communitygarden.org. Accessed 9 Nov 2012 Agbonlahor MU, Momoh S, Dipeolu AO (2007) Urban vegetable crop production and production efficiency. Int J Veg Sci 13(2):63-72. doi:10.1300/J512v13n02 06

Agrawal M, Singh B, Rajput M, Marshall F, Bell J (2003) Effect of air pollution on peri-urban agriculture: a case study. Environ Pollut 126:323-329. doi:10.1016/S0269-7491(03)00245-8

Ali M (2000) Dynamics of vegetable production, distribution and consumption in Asia. AVRDC Publication no. 00-498, Shanhua

Altieri MA, Companioni N, Canizares K, Murphy C, Rosset P, Bourque M, Nicholls C (1999) The greening of the 'Barrios': urban agriculture for food security in Cuba. Agr Hum Val 16:131140. doi:10.1023/A:1007545304561
Amoa P, Dreschel P, Abaidoo RC, Ntow WJ (2006) Pesticide and pathogen contamination of vegetables in Ghana's urban markets. Arch Environ Contam Toxicol 50:1-6. doi:10.1007/s00244-0040054-8

Armar-Klemesu M (2000) Urban agriculture and food security, nutrition and health. In: Bakker N, Dubbeling M, Guendel S, Sabel Koschella U, de Zeeuw H (eds) Growing cities, growing food, urban agriculture on the policy Agenda. Feldafing, DSE, pp 99-118

Asomani-Boateng R (2007) Closing the loop community-based organic solid waste recycling, urban gardening, and land use planning in Ghana, West Africa. J Planning Educ Res 27:132-145. doi:10.1177/ 0739456 X07306392

Aubry C, Ramamonjisoa J, Dabat MH, Rakotoarisoa J, Rakotondranibe J, Rabeharisoa L (2012) Urban agriculture and land use in cities: an approach with the multi-functionality and sustainability concepts in the case of Antananarivo (Madagascar). Land Use Policy 29:429 439. doi:10.1016/j.landusepol.2011.08.009

Ayaga G, Kibata G, Lee-Smith D, Njenga M, Rege R (2005) Policy prospects for urban and peri-urban agriculture in Kenya. Urban Harvest -International Potato Center, Lima

Bastos EA, de Andrade Júnior AS (2000) Agrometeorolgical data for Teresina city, PI (1980-1999). Embrapa Meio-Norte, Teresina

Batty M (2008) The size, scale, and shape of cities. Science 319:769 771. doi:10.1126/science. 1151419

Baud ISA (2000) Collective action, enablement, and partnership: issues in urban development. http://www.ucl.ac.uk/dpu-projects/ drivers_urb_change/urb_governance/pdf_partic_proc/IHS_Baud collective_action.pdf. Accessed 9 Nov 2012

Bhatta GD, Doppler W (2010) Socio-economic and environmental aspects of farming practices in the peri-urban hinterlands of Nepal. $\mathrm{J}$ Agr Env 11:26-39

Birley MH, Lock K (2000) The health impacts of peri-urban natural resource development. Cromwell, London. http://www.birleyhia.co. uk/Publications/periurbanhia.pdf. Accessed 9 Nov 2012

Bradley P, Marulanda C (2001) Simplified hydroponics to reduce global hunger. Acta Hort 554:289-295

Branco MC, de Alcântara FA (2012) Hortas comunitárias, vol 3: experiências do Brasil e dos Estados Unidos. Embrapa, Brasilia

Brock B, Foeken D (2006) Urban horticulture for a better environment: a case study of Cotonou, Benin. Habitat Int 30(3):558-578

Buechler S, Devi Mekala G, Keraita B (2006) Wastewater use for urban and peri-urban agriculture. In. van Veenhuizen R (ed) Cities farming for the future. Urban agriculture for sustainable cities, RUAF Foundation, IDRC and IIRR, pp 241-272

Caldeyro-Stajano M (2004) Simplified hydroponics as an appropriate technology to implement food security in urban agriculture. Practical Hydroponics Greenhouses 76:1-6

Centrès JM (1996) L'agriculture en zones urbaines et périurbaines dans deux villes sahéliennes: Bamako et Bobo Dioulasso. Cah Agric 5(5):373-381

CFSC (2011) http://www.foodsecurity.org/. Accessed 9 Nov 2012

Cissé O, Guye NFD, Sy M (2005) Institutional and legal aspects of urban agriculture in French speaking West Africa: from marginalization to legitimization. Environ Urban 17(2):143-154. doi:10.1177/ 095624780501700211

City Farmer (2011) Canada's Office of Urban Agriculture. http:// www.cityfarmer.org/. Accessed 9 Nov 2012

Citymayors (2009a) The world's largest cities and urban areas in 2006. http://www.citymayors.com/statistics/urban_2006_1.html. Accessed 9 Nov 2012

Citymayors (2009b) The world's largest cities and urban areas in 2020. http://www.citymayors.com/statistics/urban_2020_1.html. Accessed 9 Nov 2012

Coffey M, Coad A (2010) Collection of municipal solid waste in developing countries. United Nations Human Settlements Programme, UN-HABITAT, Nairobi 
Cofie OO, Kranjac-Berisavljevic G, Drechsel P (2004) The use of human waste for peri-urban agriculture in Northern Ghana. Renew Agr Food Syst 20:73-80. doi:10.1079/RAF200491

Cofie O, Bradford AA, Dreschel P (2006) Recycling of urban organic waste for urban agriculture. In. Veenhuizen $R$ van (ed) Cities farming for the future. Urban agriculture for sustainable cities, RUAF Foundation, IDRC and IIRR, pp 207-240

Cour JM (2001) The Sahel in West Africa: countries in transition to a full market economy. Global Environ Chang 11(1):31-47

Cruz MC, Medina RS (2003) Agriculture in the city: a key to sustainability in Havana, Cuba. Ian Randle, Kingston. http://www.idrc.ca/ openebooks/104-3/. Accessed 9 Nov 2012

Danso G, Drechsel P, Wiafe-Antwi T, Gyiele L (2002) Income of farming systems around Kumasi. Ghana Urban Agr Mag 7:5-6

Danso GK, Drechsel P, Akinbolu SS, Gyiele LA (2003) Review of studies and literature on the profitability and sustainability of urban and peri-urban agriculture. FAO, IWMI, Accra

De Bon H, Parrot L, Moustier P (2010) Sustainable urban agriculture in developing countries. A review. Agron Sustain Dev 30:21-32. doi:10.1051/agro:2008062

de Zeeuw H (2010) Multi-stakeholder policy formulation and action planning on urban agriculture in developing countries. Acta Hort 881:97-109

Deesohu Saydee G, Ujereh S (2003) Rooftop gardening in Senegal. Urban Agr Mag 10:16-17

Dessus S, Herrera S, de Hoyos R (2008) The impact of food inflation on urban poverty and its monetary cost: some back-of-the-envelope calculations. Agr Econ 39(Suppl):417-429

Diaz-Albertini J (1991) Non-government development organisations and the grassroots in Peru. Voluntas: Int J Volunt Nonprofit Org 2:26-57. doi:10.1007/BF01398528

Dossa LH, Abdulkadirb A, Amadoua H, Sangarec S, Schlechta E (2011) Exploring the diversity of urban and peri-urban agricultural systems in Sudano-Sahelian West Africa: an attempt towards a regional typology. Landscape Urban Plan 102:197-206. doi:10.1016/j.landurbplan.2011.04.005

Drechsel P, Graefe S, Sonou M, Cofie O (2006) Informal irrigation in urban West Africa: an overview. IWMI, Colombo. doi:10.3910/ 2009.102. Accessed 9 Nov 2012

Drescher AW (2001) Urban and peri-urban agriculture on the policy agenda. Urban Agr Mag 4:6-7

Drescher AW (2004) Food for the cities: urban agriculture in developing countries. Acta Hort 643:227-231

Drescher AW, Iaquinta D (1999) Urban and periurban agriculture: a new challenge for the UN Food and Agriculture Organisation (FAO). FAO, Rome

Eaton DJF, Hilhorst T (2003) Opportunities for managing solid waste flows in the peri-urban interface of Bamako and Ouagadougou. Environ Urban 15(1):53-64. doi:10.1177/095624780301500110

Ellis F, Sumberg J (1998) Food production, urban areas and policy response. Food Policy 26(2):213-225. doi:10.1016/S0305750X(97)10042-0

Etuah-Jackson I, Klaassen WP, Awuye JA (2001) Turning municipal waste into compost: the case of Accra. In: Drechsel P, Kunze D (eds) Waste composting for urban and peri-urban agriculture: Closing the rural-urban nutrient cycle in Sub-Saharan Africa. CABI, Wallingford, pp 84-95

Eumorphopoulos E, Aravantinos D (1998) The contribution of a planted roof to the thermal protection of buildings in Greece. Energ Buildings 27:20-36

Ezedinma C, Chukuezi C (1999) A comparative analysis of urban agricultural enterprises in Lagos and Port Harcourt. Nigeria Environ Urban 11(2):135-146

FAO (1995) Improving nutrition through home gardening: a training package for preparing field workers in Southeast Asia. Food and Nutrition Division, Rome
FAO (1996) The state of Food and Agriculture. FAO, Rome

FAO (2001) Urban and peri-urban agriculture. A briefing guide for the successful implementation of urban and peri-urban agriculture in developing countries and countries of transition. Special Programme for Food Security (SPFS). FAO, Rome. http:// www.fao.org/fileadmin/templates/FCIT/PDF/briefing_guide.pdf. Accessed 9 Nov 2012

FAO (2003) The informal food sector. Municipal support policies for operators, vol 4. Food in cities collection. FAO, Rome. ftp:// ftp.fao.org/docrep/fao/009/y4312e/y4312e00.pdf. Accessed 9 Nov 2012

FAO (2007) Profitability and sustainability of urban and peri-urban agriculture. Agricultural management, marketing and finance occasional paper no. 19. FAO, Rome. ftp://ftp.fao.org/docrep/fao/ 010/a1471e/a1471e00.pdf. Accessed 9 Nov 2012

FAO (2010) Growing greener cities. http://www.fao.org/ag/agp/ greenercities/en/resources/index.html. Accessed 9 Nov 2012

FAO-FCIT (2011) Food for the cities. http://www.fao.org/fcit/fcithome/en/. Accessed 9 Nov 2012

FAO Gender (2011) http://www.fao.org/gender/. Accessed 9 Nov 2012

FAO Greener Cities (2012) International seminar on urban and periurban agriculture. http://www.fao.org/ag/agp/greenercities/en/ events/. Accessed 9 Nov 2012

FAO Micro Gardens (2010) With micro-gardens, urban poor "grow their own". http://www.fao.org/ag/agp/greenercities/en/ microgardens/index.html. Accessed 9 Nov 2012

FAO School Gardens (2005) Setting up and running a school garden. Manual for teachers, parents and communities. http:/www.fao.org/ schoolgarden/sglibrary_en.htm. Accessed 9 Nov 2012

FAOSTAT (2012) Foods supply. http://faostat.fao.org/. Accessed 9 Nov 2012

Fecondini M, Casati M, Dimech M, Michelon N, Orsini F, Gianquinto G (2009) Improved cultivation of lettuce with a low cost soilless system in indigent areas of north-east Brazil. Acta Hort 807:501-507

Fecondini M, Damasio de Faria AC, Michelon N, Mezzetti M, Orsini F, Gianquinto G (2010) Learning the value of gardening: results from an experience of community based simplified hydroponics in north-east Brazil. Acta Hort 881:111-116

Fleury A, Ba A (2005) Multifunctionality and sustainability of urban agriculture. Urban Agr Mag 15:4-6

Foeken D, Mwangi AM (1998) Farming in the City of Nairobi. Working paper 30. African Studies Centre, Leiden

Freidberg S (1997) Contacts, contracts, and green bean schemes: liberalisation and agro-entrepreneurship in Burkina-Faso. J Mod Afr Stud 35(1):101-128

Garrett JL, Ruel MT (2000) Achieving urban food and nutrition security in the developing world. International Food Policy Research Institute, Focus 3. http://www.ifpri.org/publication/achieving-urbanfood-and-nutrition-security-developing-world. Accessed 9 Nov 2012

Gayan BT (1996) Sustaining home gardens in the city-institute and institutionalization in Baguio. Paper at UPWARD conference, December '96 Pampanga

Ghosh S (2004) Food production in cities. Acta Hort 643:233-239

Gianquinto G, Pimpini F (1991) Risultati preliminari sull'influenza dell'impiego dei reflui solidi e liquidi di depurazione delle acque urbane sugli aspetti qualitativi e quantitativi della produzione di una successione novennale di diverse specie orticole. PadovaFiere, Padova

Gianquinto G, Michelon N, Orsini F (2007a) Idroponia in un area povera del nord est del Brasile. Un esempio di cooperazione decentrata. Regione Veneto-FAO. In: Franceschetti G (ed) Agricoltura e ruralità nei paesi ad economia povera. I Percorsi dello Sviluppo. CLEUP, Padova, pp 95-106

Gianquinto G, Orsini F, Michelon N, Ferreira da Silva D, Damasio de Faria F (2007b) Improving yield of vegetables by using soilless 
micro-garden technologies in peri-urban area of North-East Brazil. Acta Hort 747:57-65

Gockowski J, Mbazoo J, Mbabh G, Moulende TF (2003) African traditional leafy vegetable and the urban and peri-urban poor. Food Policy 8:221-235. doi:10.1016/S0306-91920300029-0

Goossens F (1997) Commercialisation des vivres locaux le secteur informel dans une perspective dynamique. Collection Aliments dans les Villes. ftp://ftp.fao.org/DOCREP/fao/003/x6985f/ x6985f00.pdf. Accessed 9 Nov 2012

Graefe S, Schlecht E, Buerket A (2008) Opportunities and challenges of urban and peri-urban agriculture in Niamey. Niger Outlook Agr 37:47-56. doi:10.5367/000000008783883564

Harris TB, Manning WJ (2010) Nitrogen dioxide in the urban forest. Acta Hort 881:505-509

Holmer RJ, Drescher AW (2005) Allotment gardens of Cagayan de Oro: their contribution to food security and urban environmental management. In Knie C (ed) Urban and peri-urban developments - structures, processes and solutions. SAGSSP, pp. 149-155

Holmer RJ, Clavejo MT, Dongus S, Drescher A (2003) Allotment gardens for Philippine cities. Urban Agr Mag 11:29-31

IBGE (2004) Pesquisa de Orçamentos Familiares 2002-2003: Aquisição alimentar domiciliar per capita, Brasil e Grandes Regiões. IBGE, Rio de Janeiro

IDRC (2011) http://www.idrc.ca/en/ev-92997-201-1-DO TOPIC.html. Accessed 9 Nov 2012

IIED (2011) The Human Settlements Programme. http://www.iied.org/. Accessed 9 Nov 2012

Institute of Simplified Hydroponics (2011) http://www.carbon.org/. Accessed 9 Nov 2012

Israel E (2008) In "Eat local" movement, Cuba is years ahead. Reuters, December 15, 2008. http://www.reuters.com/article/2008/12/16/ us-cuba-food-idUSTRE4BF01H20081216? $\mathrm{sp}=$ true. Accessed 9 Nov 2012

Izquierdo J (2007) Simplified hydroponics, a tool for food security in Latin America and the Caribbean. Acta Hort 742:67-74

Jansen HGP, Midmore DJ, Binh PT, Valasayya S, Tru LC (1996) Profitability and sustainability of peri-urban vegetable production systems in Vietnam. Neth J Agr Sci 44:125-143

Jonsson P (2004) Vegetation as an urban climate control in the subtropical city of Gaborone, Botswana. Int J Climatol 24:13071322. doi:10.1002/joc. 1064

Kahane R, Temple L, Brat P, de Bon H (2005) Les légumes feuilles des pays tropicaux: diversité, richesse économique et valeur santé dans un contexte très fragile. In: Parrot L, Njoya A, Temple L, AssogbaKomlan F, Kahane R, Ba Diao M, Havard M (eds) Agricultures et développement urbain en Afrique subsaharienne: Environnement et enjeux sanitaires. Editions L'Harmattan, pp. 119-129

Karanja N, Njenga M, Prain G, Kangethe E, Kironchi G, Githuku C, Kinyari P, Mutua GK (2010) Assessment of environmental and public health hazards in wastewater used for urban agriculture in Nairobi Kenya. Tropic Subtropic Agroecosyst 12:85-97

Kessler A, Helbig J (2001) Adding value to compost from urban household and market refuse in Lomé. In: Drechsel P, Kunze D (eds) Waste composting for urban and periurban agriculture -closing the rural-urban nutrient cycle in sub-Saharan Africa. IWMI/FAO/CABI, Wallingford, pp 133-136. doi:10.1079/9780851995489.0133

Khosa T, Averbeke W, van Böhringer R, Maswikaneng J, Albertse E (2003) The 'Drum and Drip' micro-irrigation system, tested in South Africa. Urban Agr Mag 10:4-5

Klinkenberg E, Amerasinghe FP (2006) Risk assessment: malaria in urban and peri-urban agriculture. Resource paper 2. In Boischio A, Clegg A, Mwagore D (eds) Health risks and benefits of urban and peri-urban agriculture and livestock (UA) in sub-Saharan Africa. Urban Poverty and Environment, IDRC Series Rep. No. 1, pp 35-46. http://idl-bnc.idrc.ca/dspace/bitstream/10625/35531/ 1/127428.pdf. Accessed 9 Nov 2012
Klinkenberg E, McCall PJ, Wilson MD, Amerasinghe FP, Donnelly MJ (2008) Impact of urban agriculture on malaria vectors in Accra. Ghana Malaria J 7:151. doi:10.1186/1475-2875-7-151, http://www.malariajournal.com/content/7/1/151. Accessed 9 november 2012

Konijnendijk C, Gauthier M (2006) Urban forestry for multifunctional urban land use. In. Veenhuizen R. van (ed) Cities farming for the future. Urban agriculture for sustainable cities, RUAF Foundation, IDRC and IIRR, pp 411-442

Kundall S (1995) Rooftop gardening in Bogota. Choices No. 27. UNDP, NewYork

La Molina (2012) Centro de Investigación de Hidroponía y Nutrición Mineral, Universidad Nacional Agraria La Molina, Lima, Perù. http://www.lamolina.edu.pe/FACULTAD/ciencias/hidroponia/ default.htm. Accessed 9 Nov 2012

Lam NT, Khoi HH (1999) Daily nutrient requirements and vegetable consumption by Vietnamese people. In: De Bon H (ed) National workshop on safe and year-round vegetable production in peri-urban areas, 15-16 December 1999. RIFAV and CIRAD, Hanoi, pp 65-74

Lemeilleur S, Temple L, Kwa M (2003) Identification of banana production systems in urban and peri-urban agriculture in Yaoundé. InfoMusa 12:13-16

Livelihoods Connect (2011) http://www.eldis.org/go/livelihoods/. Accessed 9 Nov 2012

Mapanda F, Mangwayana EN, Nyamangara J, Giller KE (2007) Uptake of heavy metals by vegetables irrigated using wastewater and the subsequent risks in Harare, Zimbabwe. Phys Chem Earth 32:1399-1405. doi:10.1016/j.pce.2007.07.046

Marulanda C, Izquierdo J (2003) Manual tecnico: La huerta hidroponica popular. Curso audiovisual. FAO, Oficina Regional para America Latina y el Caribe, Santiago

Mavrogianopoulos G, Vogli V, Kyritsis S (2002) Use of wastewater as a nutrient solution in a closed gravel hydroponic culture of giant reed (Arundo donax). Biores Technol 82:103-107. doi:10.1016/ S0960-8524(01)00180-8

Mawois M, Aubry C, Le Bail M (2011) Can farmers extend their cultivation areas in urban agriculture? A contribution from agronomic analysis of market gardening systems around Mahajanga (Madagascar). Land Use Policy 28:434-445. doi:10.1016/ j.landusepol.2010.09.004

Maxwell D, Levin C, Csete J (1998) Does urban agriculture help prevent malnutrition? Evidence from Kampala. Food Policy 23:411-424. doi:10.1016/S0306-9192(98)00047-5

Mbiba B (1995) Urban agriculture in Zimbabwe. Ashgate, Surrey

Méndez V, Lok R, Somarriba E (2001) Interdisciplinary analysis of homegardens in Nicaragua: micro- zonation, plant use and socioeconomic importance. Agroforest Syst 51:85-96. doi:10.1023/ A:1010622430223

Mezzetti M, Orsini F, Fecondini M, Michelon N, Gianquinto G (2010) Women and simplified hydroponics: community gardening as a way of emancipation in Trujillo, Peru. Acta Hort 881:169-172

Midmore DJ, Jansen HGP (2003) Supplying vegetables to Asian cities: is there a case for peri-urban production? Food Policy 28:14-23. doi:10.1016/S0306-9192(02)00067-2

Monteiro JPR, Monteiro MSL (2006) Hortas comunitárias de Teresina: agricultura urbana e perspectiva de desenvolvimento local. Revista Iberoamericana de Economía Ecológica 5:47-60

Moskow A (1999) Havana's self-provision gardens. Envir Urban 11:127-134. doi:10.1177/095624789901100211

Mougeot LJA (1994) Urban food production: evaluation, official support and significance. Cities feeding people series. Report no. 8 . IDRC, Ottawa

Mougeot LJA (2000) Urban agriculture: definition, presence, potentials and risks. In. van Veenhuizen R (ed) Cities farming for the future. Urban agriculture for sustainable cities, RUAF Foundation, IDRC and IIRR, pp 1-42 
Mougeot LJA (2005) Urban agriculture and the millennium development goals. In: Mougeot LJA (ed) AGROPOLIS. The social, political and environmental dimensions of urban agriculture. Earthscan, London. www.earthscan.co.uk

Moustier P, Danso G (2006) Local economic development and marketing of urban produced food. In: van Veenhuizen R (ed) Cities farming for the future. Urban agriculture for sustainable cities, RUAF Foundation, IDRC and IIRR, pp 171-206

Moustier P, David O (1997) Etude de cas de la dynamique du maraîchage périurbain en Afrique sub-saharienne. Document FAO N-DT/02/96. FAO, Rome

Moustier P, Figuié M, Loc NTT, Son HT (2006) The role of coordination in the safe and organic vegetable chains supplyinh Hanoi. Acta Hort 699:297-306

Murphy C (1999) Cultivating Havana: urban agriculture and food security in the years of crisis. Development report no. 12, Food First, Institute for Food and Development Policy. http:// www.foodfirst.org/en/node/273. Accessed 9 Nov 2012

Norman MJT, Pearson CJ, Searle PGE (1995) The ecology of tropical food crops in their environment. Cambridge University Press, Cambridge. doi:10.1017/CBO9781139172479

Novo MG, Murphy C (2000) Urban agriculture in the city of Havana: a popular response to crisis. In: Bakker N, Dubbeling M, Guendel S, Sabel Koschella U, de Zeeuw H (eds) Growing cities, growing food, urban agriculture on the policy agenda. DSE, Feldafing, pp 329-348

Obosu-Mensah K (1999) Food production in urban areas. A study of urban agriculture in Accra, Ghana. Ashgate, Surrey

Obosu-Mensah K (2002) Changes in official attitudes towards urban agriculture in Accra. Afric Stud Quart 6:19-32

Obuobie E, Keraita B, Danso G, Amoah P, Cofie OO, Raschid-Sally L, Drechsel P (2006) Irrigated urban vegetable production in Ghana: characteristics, benefits and risks. IWMI-RUAF-CPWF, Accra: International Water Management Institute. p 150. http://www.city farmer.org/GhanaIrrigateVegis.html. Accessed 9 Nov 2012

Odai SN, Memah E, Sipitey D, Ryo S, Awuah E (2008) Heavy metals uptake by vegetables cultivated on urban waste dumpsites: case study of Kumasi, Ghana. Res J Environ Toxicol 2:92-99. doi:10.3923/rjet.2008.92.99

Onyango CM, Shibairo SI, Imungi JK, Harbinson J (2008) The physico-chemical characteristics and some nutritional values of vegetable amaranth sold in Nairobi-Kenya. Ecol Food Nutr 47:382-398. doi:10.1080/03670240802003926

Orsini F, Michelon N, Scocozza F, Gianquinto G (2009) Farmers-toconsumers: an example of sustainable soilless horticulture in urban and peri-urban areas. Acta Hort 809:209-220

Orsini F, Morbello M, Fecondini M, Gianquinto G (2010a) Hydroponic gardens: undertaking malnutrition and poverty through vegetable production in the suburbs of Lima, Peru. Acta Hort 881:173-178

Orsini F, Fecondini M, Mezzetti M, Gianquinto G (2010b) Simplified hydroponic floating systems for vegetable production in Trujillo, Peru. Acta Hort 881:157-162

Orsini F, Mezzetti M, Fecondini M, Gianquinto G (2010c) Simplified substrate soilless culture for vegetable production in Trujillo, Peru. Acta Hort 881:163-168

Oths KS (1998) Assessing variation in health status in the Andes: a biocultural model. Soc Sci Med 47:1017-1030. doi:10.1016/ S0277-9536(98)00161-0

Pandey J, Pandey U (2009) Accumulation of heavy metals in dietary vegetables and cultivated soil horizon in organic farming system in relation to atmospheric deposition in a seasonally dry tropical region of India. Environ Monit Assess 148:61-74. doi:10.1007/ s10661-007-0139-8

Phuong Anh MT (2000) Current status and prospective planning upon agricultural development in Hanoi. CG Strategic Initiative of Urban and Peri-Urban Agriculture workshop, 5-9 June 2000, Hanoi
Piel G (1997) The urbanization of poverty worldwide. Challenge 40:58-68

Portal dos Convênios (2012) http://api.convenios.gov.br/siconv/dados/ convenio/774227.html . Accessed 19 Dec 2012

Potutan GE, Schnitzler WH, Arnado JM, Janubas LG, Holmer RJ (2000) Urban agriculture in Cagayan de Oro: a favourable response of city government and NGOs. In: Bakker N, Dubbeling M, Guendel S, Sabel Koschella U, de Zeeuw H (eds) Growing cities, growing food, urban agriculture on the policy Agenda. DSE, Feldafing, pp 413-428

Prain G (2006) Integrated urban management of local agricultural development: the policy arena in Cuba. In: Veenhuizen $\mathrm{R}$ van (ed) Cities farming for the future. Urban agriculture for sustainable cities, RUAF Foundation, IDRC and IIRR, pp 308-311

Prain G (2010) Effects of the global financial crisis on the food security of poor urban households. RUAF Foundation, UN-HABITAT and IDRC, Leusden. http://www.ruaf.org/node/2259. Accessed 9 Nov 2012

Prain G, Karanja N, Lee-Smith D (2010) African urban harvest. Agriculture in the cities of Cameroon, Kenya and Uganda. IDRC, Ottawa, and CIP, Springer, Lima

ProHuerta (2011) http://www.inta.gov.ar/extension/prohuerta/. Accessed 9 Nov 2012

Prolinnova (2011) http://www.prolinnova.net/. Accessed 9 november 2012.

Purnomohadi N (2000) Jakarta: Urban Agriculture as an alternative strategy to face the economic crisis. In: Bakker N, Dubbeling M, Guendel S, Sabel Koschella U, de Zeeuw H (eds) Growing cities, growing food, urban agriculture on the policy Agenda. DSE, Feldafing, pp 453-466

PUVEP (2011) Periurban vegetable project. Xavier University, Cagayan de Oro City. http://puvep.xu.edu.ph/. Accessed 9 Nov 2012

Ratta A, Nasr J (1996) Urban agriculture and the African urban food supply system. TUAN, New York

Redwood M (2008) Agriculture in urban planning: generating livelihoods and food security. IDRC, Ottawa

Rios JA (2003) Hydroponics technology in urban Lima, Peru. Urban Agr Mag 10:9-10

Rodríguez-Delfín A, Hoyos M, Chang M (2001) Soluciones Nutritivas en Hidroponía: Formulación y preparación. Centro de Investigación de Hidroponía y Nutrición Mineral, Universidad Nacional Agraria La Molina, Lima

Rosset P, Benjamín M (1994) The greening of the revolution. Cuba's experiment with organic agriculture. Ocean Press, Melbourne

Ruel MT, Garrett JL, Morris SS, Maxwell DG, Oshaug A. Engle PL, Menon P, Slack AT, Haddad LJ (1998) Urban challenges to food and nutrition security: a review of food security, health, and care giving in the cities. IFPRI, Washington. http://www.ifpri.org/sites/default/files/publications/dp51.pdf. Accessed 9 Nov 2012

Sabel-Koschella U, Jacobi P, Amend J (1998) Urban leafy vegetable production in Dar-es-Salaam. Urban Vegetable Promotion Project, GTZ, Dar-es-Salaam

Sanchez PA (1976) Properties and management of soils in the tropics. Wiley, New York

Satterthwaite D, McGranahan G, Tacoli C (2010) Urbanization and its implications for food and farming. Phil Trans R Soc B 365:28092820. doi:10.1098/rstb.2010.0136

Säumel I, Kotsyuk I, Hölscher M, Lenkereit C, Weber F, Kowarik I (2012) How healthy is urban horticulture in high traffic areas? Trace metal concentrations in vegetable crops from plantings within inner city neighbourhoods in Berlin, Germany. Env Pollut 165:124-132. doi:10.1016/j.envpol.2012.02.019

ScienceDaily (2007) Mayday 23: world population becomes more urban than rural. http://www.sciencedaily.com/releases/2007/05/ 070525000642.htm. Accessed 9 Nov 2012 
Shackleton CMM, Pasquini MW, Drescher AW (2009) African indigenous vegetables in urban agriculture. Earthscan, London. ISBN 978-18440-771-5-1

Shariful Islam KM (2004) Rooftop gardening as a strategy of urban agriculture for food security: the case of Dhaka City, Bangladesh. Acta Hort 643:241-247

Skeffington MS (2006) Organic fruit and vegetable growing as a national policy: The Cuban story. Energy Bulletin/FEASTA, http:// www.energybulletin.net/node/13067. Accessed 9 november 2012

Smit J, Bailkey M (2006) Urban Agriculture and the Building of Communities. In. van Veenhuizen R (ed) Cities farming for the future. Urban agriculture for sustainable cities, RUAF Foundation, IDRC and IIRR, pp 145-170

Smit J, Ratta A, Nasr J (1996) Urban Agriculture - Food, Jobs and Sustainable Cities. UNDP, New York

Smith F, Eyzaguirre P (2007) African leafy vegetables: their role in the World Health Organization's global fruit and vegetable initiative. Afr J Food Agric Nutrition Dev 7 (3). Unpaginated

Tabares CM (2003) Hydroponics in Latin America. Urban Agr Mag 10:8

Temple L, Moustier P (2004) Functions and constraints of urban and periurban agriculture in three African cities (Yaoundé, Cotonou, Dakar). Cahiers Agricultures 13:15-22

Temu AE, Temu AA (2006) High value agricultural products for smallholder markets in sub-Saharan Africa: Trends, opportunities and research priorities. Cali, Colombia, CIAT. www.tanzania gateway.org/docs/HighValAgricProdsforSmallholdermkts.pdf. Accessed 9 november 2012

Tixier P, de Bon H (2006). Urban Horticulture. In: van Veenhuizen R (ed) Cities farming for the future. Urban agriculture for sustainable cities, RUAF Foundation, IDRC and IIRR, pp 313-346

Trainer T (1995) The Conserver Society - Alternatives for Sustainability. Chapter 3. Food and Agriculture. Zed Books, London

UN-DESA (2007) World population prospects: the 2007 revision population database. Population Division of the Department of Economic and Social Affairs of the United Nations Secretariat, http://esa.un.org/unup. Accessed 9 november 2012

UNDP (1996) Urban agriculture. Food, jobs and sustainable cities. UNDP, New York

UNFPA (2007) State of world population 2007: unleashing the potential of urban growth. United Nations Population Fund (UNFPA), New York. http://www.unfpa.org/swp/2007/presskit/pdf/sowp 2007 eng.pdf. Accessed 9 Nov 2012

UN-HABITAT (2008a) State of the world's cities 2008/09. Earthscan, London. http://www.unhabitat.org.jo/en/inp/Upload/105056 Cover\%20page.pdf. Accessed 9 Nov 2012

UN-HABITAT (2008b) State of African Cities 2008. A framework for addressing urban challenges in Africa. Nairobi, Kenya: UNHABITAT. http://www.google.it/url? sa=t\&rct=j\&q=\&esrc= $\mathrm{s} \&$ frm $=1 \&$ source $=$ web \& $\mathrm{cd}=1 \& \mathrm{ved}=0$ CEoQFjAA\&url $=$ http $\% 3 \mathrm{~A} \% 2 \mathrm{~F} \% 2 \mathrm{Fwww}$.unhabitat.org\%2Fpmss\%2FgetElectronic Version.asp\%3Fnr\%3D2574\%26alt\%3D1\&ei=bUYZUJz
3O6T04QTd9oHQBg\&usg=AFQjCNH4OiBS y IHx Vusywe4TgWhvfwTU7A\&sig2=hpDRvjXxFJv8B7cWQX-5Lw. Accessed 9 Nov 2012.

UN-HABITAT (2010) Urban world, issue 2, vol 3. UN-HABITAT, Nairobi

Urban Harvest, CGIAR (2011) http://www.uharvest.org/. Accessed 9 Nov 2012

UWEX (2011) University of Wisconsin-Extension, urban horticulture. http://www.uwex.edu/ces/wihort/. Accessed 9 Nov 2012

van Veenhuizen R (2006) Cities farming for the future. Urban agriculture for sustainable cities, RUAF Foundation, IDRC and IIRR

Velez-Guerra A (2004) Multiple means of access to land for urban agriculture: a case study of farmers' groups in Bamako, Mali. IDRC Cities Feeding People report series 40. IDRC, Ottawa

Villas-Boas MLS (2006) How community gardens function: a case study of "Complexo Aeroporto", Ribeirao Preto, S.P. Brazil. MSc thesis, Faculty of the College of Arts and Sciences, University of Ohio, Cincinnati, OH, USA. http://etd.ohiolink.edu/send-pdf.cgi/ VillasB244as\%20Maria\%20L250cia\%20Soares.pdf?ohiou 11 49463363. Accessed 9 Nov 2012

Viney S, Cattane V, Al-Youm AM (2011) Vertical and rooftop agriculture gain momentum in Cairo, Egypt. City Farmer News. http:// www.cityfarmer.info/2011/07/04/vertical-and-rooftop-agriculturegain-momentum-in-cairo-egypt/. Accessed 9 Nov 2012

Weinberger KM, Lumpkin TA (2005) Horticulture for poverty alleviation - the unfunded revolution. AVRDC Working Paper No. 15. http://ssrn.com/abstract=781784. Accessed 9 NOv 2012. doi: $10.2139 /$ ssrn. 781784

WHO (2003) Diet, nutrition and the prevention of chronic diseases: report of a joint WHO/FAO expert consultation. WHO Technical Report Series no. 916. WHO, Geneva. http://www.fao.org/docrep/ 005/AC911E/AC911E00.HTM. Accessed 9 Nov 2012

WHO (2006) Guidelines for the safe use of wastewater, excreta and greywater, vol 4: excreta and greywater use in agriculture. WHO, Paris

Wong N, Cheong D, Yan H, Soh J, Ong C, Sia A (2003) The effect of rooftop garden on energy consumption of a commercial building in Singapore. Energ Buildings 35:353-364. doi:10.1016/S03787788(02)00108-1

Yi-Zhang C, Zhangen Z (2000) Shanghai: trends towards specialised and capital intensive urban agriculture. In: Bakker N, Dubbeling $M$, Guendel S, Sabel Koschella U, de Zeeuw H (eds) Growing cities, growing food, urban agriculture on the policy Agenda. DSE, Feldafing, pp 467-475

Zezza A, Tasciotti L (2010) Urban agriculture, poverty and food security: empirical evidence from a sample of developing countries. Food Policy 35:265-273. doi:10.1016/j.foodpol.2010.04.007

Zezza A, Azzarri C, Davis B, Covarrubias K, Tasciotti L, Anriquez G (2008) The impact of rising food prices on the poor. FAO-ESA Working Paper 08-07 